\title{
5. PROVENANCE OF SAND DEPOSITED IN THE SANTA BARBARA BASIN AT SITE 893 DURING THE LAST 155,000 YEARS ${ }^{1}$
}

\author{
Kathleen M. Marsaglia, ${ }^{2}$ Karl C. Rimkus, ${ }^{2}$ and Richard J. Behl ${ }^{3}$
}

\begin{abstract}
Sand layers recovered at Ocean Drilling Program Site 893 in the Santa Barbara Basin were sampled and petrographically analyzed to determine their provenance. Sand deposited at this site is quartzo-feldspathic with a minor lithic component. Plagioclase feldspar dominates over potassium feldspar, and sedimentary and metamorphic lithic fragments are more common than volcanic lithic fragments. Sand detrital modes are consistent with a source along the eastern flank of the Santa Barbara Basin, most probably a combination of the Santa Clara and Ventura rivers. Compositional trends observed within the thickest subunit (IC) can be explained in part by the lengthening of the Santa Clara River channel and the merging of the Santa Clara and Ventura river drainages with falling sea level.
\end{abstract}

\section{INTRODUCTION}

In conjunction with Ocean Drilling Program (ODP) Leg 146, a single site (893) was drilled in the Santa Barbara Basin, offshore southern California (Fig. 1).Cores recovered at Site 893 consist predominantly of hemipelagic mud (silty clay) with both siliceous and calcareous biogenic components (Kennett, Baldauf, et al., 1994). The Shore-based Scientific Party (1994) subdivided the sequence into laminated ( $1 \mathrm{~A}$ and ID), nonlaminated (IB and IE), and intermittently laminated (IC and IF) subunits (Fig. 2). Individual light (diatomaceous) and dark (terrigenous) lamination pairs (varves) within the laminated intervals reflect seasonal changes in sediment supply (Pl. 1; Hülsemann and Emery, 1961; Fleischer, 1972; Soutar and Crill, 1977; Schimmelmann et al., 1992; Shore-based Scientific Party, 1994). Very thin to thick beds of sand occur at various intervals in this flat-lying basinal sequence, making up approximately $4 \%$ of the total stratigraphic thickness (Behl, this volume); these are most abundant in the intermittently laminated subunits (1C and 1F; PI. 1). Both sandy and muddy sediments are unconsolidated; consequently, the thicker sand beds were greatly disturbed during coring. Better preserved sand beds are massive to normally graded with sharp bases, and were interpreted to be turbidites or basin-floor channel deposits (Shore-based Scientific Party, 1994).

The upper Quaternary $(<160,000 \mathrm{yr}$; Ingram and Kennett, this volume), hemipelagic section recovered at Site 893 provides a highresolution paleoclimatic/paleoenvironmental record of the southern California borderland province. Alternating laminated and homogenized intervals at this site, based in part on benthic foraminiferal assemblages, represent poor- and well-oxygenated bottom conditions, respectively (Shore-based Scientific Party, 1994). These cyclic changes in lithofacies and biofacies can be loosely tied to glacial/interglacial oscillations and global changes in deep-water circulation. Two broad cycles of intermittently laminated/nonlaminated/laminated sediments are apparent (Fig. 2); these represent the last two glacial cycles of the Quaternary (Shore-based Scientific Party, 1994; Kennett, this volume).

'Kennett, J.P., Baldauf, J.G., and Lyle, M. (Eds.), 1995. Proc. ODP, Sci. Results. 146 (Pt. 2): College Station, TX (Ocean Drilling Program).

2Department of Geological Sciences. The University of Texas at El Paso, El Paso, TX 79968, U.S.A.

${ }^{3}$ Marine Science Institute, University of California, Santa Barbara, Santa Barbara. CA $93106-6150$, U.S.A.
Sand input to the center of the Santa Barbara Basin was minimized during sea-level highstands and lowstands, and maximized during periods of intermediate sea level. During a highstand, sand is sequestered on the shelf, and then as sea level falls, sand is delivered to the basin floor; most of the sand at Site 893 was deposited when sea level was between 70 and $90 \mathrm{~m}$ below present (Behl, this volume). At maximum lowstand, sand input again is minimal owing to depletion of shelf reservoirs and/or sediment bypassing (Shore-based Scientific Party, 1994). At present, sand is trapped on the shelf, locally winnowed by currents, and transported to the southeast by longshore currents (Drake et al., 1972; Fan, 1976; Kolpack, 1986; Thornton, 1981, 1984). River sediment supplied to the basin is primarily fine suspended load, and, as a result, surficial basin sediments contain $<5 \%$ sand (Thornton, 1981, 1984); over $95 \%$ of the cored interval at Site 893 contains a similar sand percentage.

The purpose of this study was to petrographically analyze sand from Site 893 (Hole 893A) and to determine its provenance. We wished to test the hypothesis that climatic and oceanographic changes in this region are reflected in compositional variations within the coarse fraction of the basin's sedimentary fill. In order to more closely tie Site 893 samples to their likely coastal source(s), we also analyzed beach and stream sand from the surrounding region (Fig. 1). Our results suggest that the most likely source of sand at Site 893 over the past $160,000 \mathrm{yr}$ was a combination of the Santa Clara and Ventura Rivers. This finding is consistent with results of other studies that focused on the Holocene and modern settings (Fleischer, 1972; Thornton, 1984).

\section{REGIONAL SETTING}

The Santa Barbara Basin is a submerged part of the Transverse Range Province of Southern California. It is flanked to the north and east by the California coast, and to the south by the Channel Islands (Fig. 1). This region is tectonically active (transpressional setting; Reed and Hollister, 1936; Vedder et al., 1969; Yeats, 1983), with the main east-west-trending structural features controlling onshore topography and drainage and offshore basin configuration. The present basin configuration (margins, sills, and intrabasinal ridges) was produced during the Pasadenan orogeny, a major late Quaternary tectonic episode (Fischer, 1972; Ingle, 1980; Thornton, 1981; Shaw and Suppe, 1994; Yeats, 1983).

The Santa Barbara Basin is semi-enclosed, with a sill depth of approximately 475 m (Fleischer, 1972; Shore-based Scientific Party, 1994). The margins of the basin contain no modern major submarine 


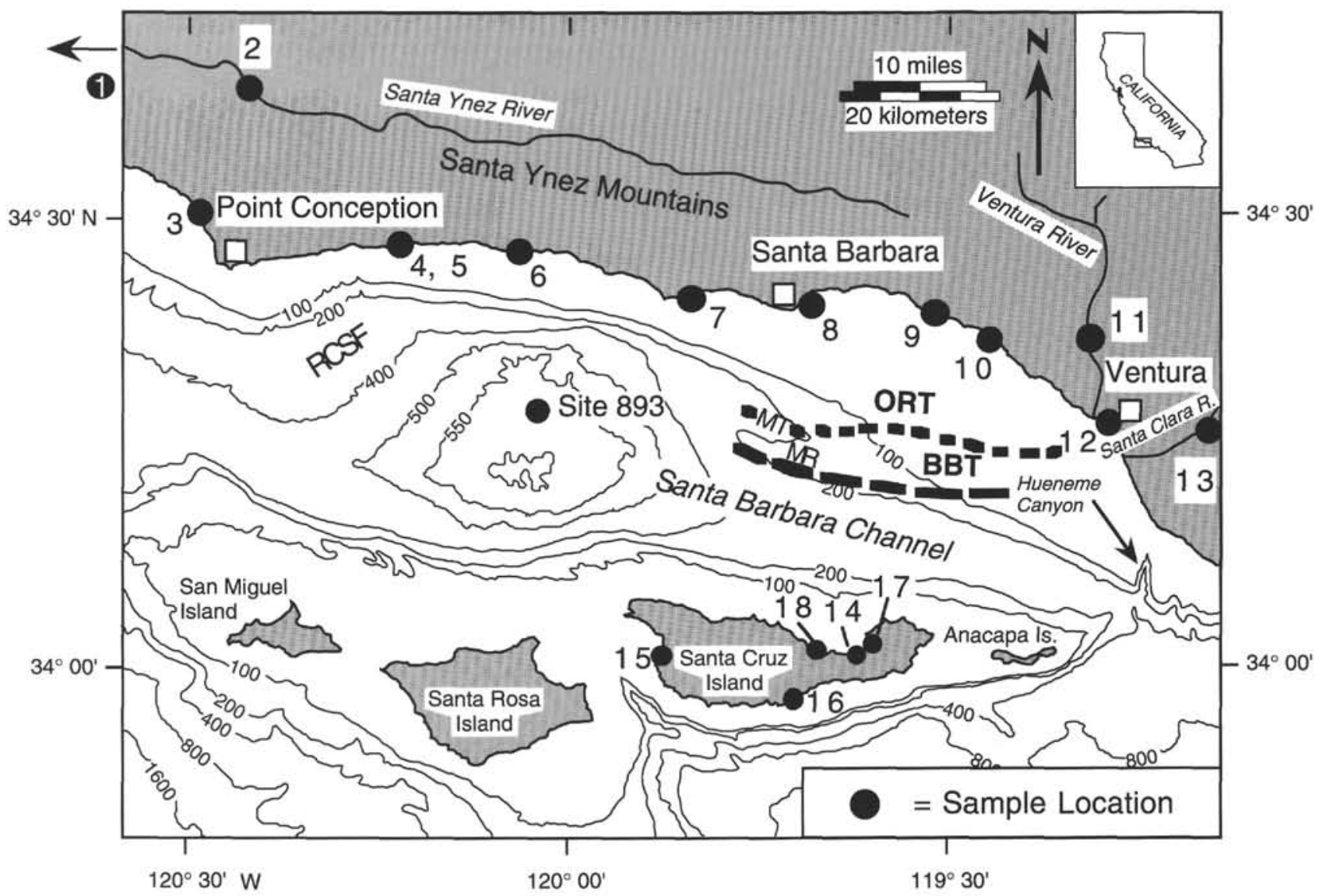

Figure 1. Location map indicating position of Site 893 in the Santa Barbara Basin, and various beach and stream sample locations (1-18). Sample I (northwest edge of map) was collected from the beach near Surf, $\mathrm{CA} . \mathrm{RCSF}=$ relict Conception submarine fan; $\mathrm{MT}=\mathrm{Montalvo}$ Trough; $\mathrm{MR}=\mathrm{Montalvo}$ Ridge; $\mathrm{BBT}=$ Blue Bottle Trend (anticline); ORT = Oak Ridge Trend (kink band). Location of ORT and BBT after Shaw and Suppe (1994). Modified from Kennett, Baldauf, et al. (1994). Bathymetry is in meters.

canyons; only two small submarine valleys occur on its northwest flank (Thornton, 1984). During the last glacial maximum ( 20 ka), sea level had dropped approximately $120 \mathrm{~m}$, greatly reducing the size of the submarine basin and restricting flow through the basin as a result of exposure of shelf areas around the Channel Islands. Therefore, during Pleistocene lowstands, the basin was flanked to the south by an amalgamated Channel Island (Santarosae Island) and separated from the California mainland by only a narrow channel (Shore-based Scientific Party, 1994, fig. 17, p. 35). At the last lowstand, the Ventura River may have joined the Santa Clara River just south of Ventura, and then drained into the Hueneme Canyon and the Santa Monica Basin to the south (Shore-based Scientific Party, 1994). Variations in sand supply to the Santa Barbara Basin may be tied to this sediment bypassing, but may also be a function of size and depletion rate of shelf sand reservoirs.

The Santa Clara and Ventura rivers are the major rivers that empty into the Santa Barbara Basin (Fig. 1). Today, the Santa Clara River follows the Santa Clara syncline north of the Oak Ridge fault (Jennings, 1977). Outcrops of granitic and schistose basement rocks and Miocene volcanic rocks are confined to the headwaters of this river (Fan 1976; Valles, 1985). In the lower reaches, the Santa Clara River is flanked by the Santa Ynez Mountains to the north and the Santa Susana Mountains to the south; both consist of uplifted Eocene to Quaternary sedimentary sequences. The Ventura River drains similar sedimentary sequences. The structural trends that presently confine the lower reaches of the Santa Clara can be traced offshore to neotectonic features: the Blue Bottle Trend (anticline) associated with the Montalvo Ridge and the Oak Ridge Trend (kink band) associated with the Montalvo Trough (Fig. 1). These structural features show evidence of truncation and growth during the Quaternary (Shaw and Suppe, 1994); therefore, they probably influenced drainage development and sediment transport during Quaternary lowstands. Seismicreflection data also indicate the presence of a Pliocene-Pleistocene prograding deltaic wedge at the southern boundary of the Oak Ridge kink band (see fig. 8 in Shaw and Suppe, 1994).

Fischer (1976) and Gorsline et al. (1982) have proposed that during previous lowstands, the Ventura and Santa Clara rivers combined to flow to the south through the Hueneme Canyon into the Santa Monica Basin. This Santa Clara-Ventura River could have crossed through the structural gap between onshore (Oak Ridge Fault) and offshore trends proposed by Shaw and Suppe (1994) (BBT, ORT in Fig. 1). The deposition of sand at Site 863 in the Santa Barbara Basin during intermediate sea levels and the absence of sand during maximum lowstands are consistent with shifts in drainage at maximum lowstand.

The minor streams and rills that drain the Channel Islands and the Santa Ynez Mountains along the Santa Barbara coast supply some sand to nearshore/shoreface regions; in addition, longshore currents transport sediment derived from the Santa Ynez River and other sources north of Point Conception into the western part of the Santa Barbara Basin (Fleischer, 1972; Kolpack, 1986; Trask, 1952).

\section{PREVIOUS STUDIES}

Given the fine grain size of surficial sediment within the Santa Barbara Basin (mean grain size of $3 \mu \mathrm{m}$; Behl, this volume), silt and 
clay-mineral provenance has been emphasized in the literature (e.g., Fan, 1976; Fleischer, 1972). Based on relative drainage basin sizes and clay mineralogy, Fleischer (1972) concluded that the Santa Clara River is most likely the dominant source of silt and clay recovered in a 6- $\mathrm{m}$ piston core from the center of the Santa Barbara Basin (equivalent to the upper part of Subunit 1A at Hole 893A). The frequency of silt layers was tied to 100-yr flood events (Fleischer, 1972).

Sand recovered at Site 893 was most likely supplied to the basin as a consequence of enhanced river runoff after winter storms (Drake et al., 1972; Fan, 1976) and subsequent subaqueous gravity flow. At present, Santa Clara River sand is transported chiefly southward by longshore currents with only a minor fraction being carried basinward by the offshore counter-current (Drake et al., 1972; Fan, 1976). Seismic events in this tectonically active region may have also triggered sand input to the basin as a result of shelf collapse. Hole 893A was drilled just a few kilometers south of a large rectangular slump, $20 \mathrm{~km}$ long, $10 \mathrm{~km}$ wide, oriented east-west, and initiating near the 200-m bathymetric contour (Vedder et al., 1986; Thornton, 1984; McCulloch, 1989). Evidence of recent mass movement, particularly debris flows, is found throughout the basin (Thornton, 1981, 1984).

Because the sand on the shelf is localized, previous sand provenance studies in the Santa Barbara Basin region have focused on modern coastal and fluvial sediments. A few studies have been conducted: Rice et al. (1976) and Trask (1952) examined the dense mineral fractions of coastal sand samples, whereas Valles (1985) and Ingersoll et al. (1993) concentrated on the light mineral and lithic fractions of sand from the Santa Clara River and its drainage basin.

\section{METHODS}

Samples of sandy sediment were taken from cores recovered at Hole 893A during shore-based description (Fig. 2). Eighteen beach and stream samples from the region were also collected for compositional comparison (Fig. 1). All samples were air-dried and then lightly sieved by hand in order to separate the sand fraction $(0.0625-2$ $\mathrm{mm}$ ). Of the 19 samples collected from the Hole $893 \mathrm{~A}$ cores, only 15 contained sufficient sand for petrographic analysis; sample intervals for the latter subset are indicated in Figure 2.

Thin sections prepared from sand concentrates were stained for both calcium- and potassium-rich feldspar using the method outlined in Marsaglia and Tazaki (1992). A total of up to 400 points was counted on each section using the Gazzi-Dickinson method, which minimizes the effects of grain-size variation on composition (Dickinson, 1970; Ingersoll et al., 1984). Grid spacings were used that maximized coverage of the thin section and were larger than the maximum grain size. Point totals are lower (100-300) for coarser beach and stream samples and sand-poor samples from Hole 893A. Counted grains were placed into 27 monomineralic and polymineralic compositional categories (Appendix A). Raw point-count data are presented in Appendix B. Parameters recalculated from these data are defined in Appendix A and presented in Appendix B (note: depths listed in Appendix B are the void-corrected depths, and age assignments are based on ${ }^{14} \mathrm{C}$ and $\mathrm{O}$-isotope chronology from Ingram and Kennett, this volume). Grain-size estimates reflect the dominant sand-size category petrographically estimated for each sample, and relative bed thicknesses are from Kennett, Baldauf, et al. (1994) (Appendix B).

\section{GENERAL DESCRIPTION AND DETRITAL MODES Hole 893A Sand}

Sand samples from Hole $893 \mathrm{~A}$ are predominantly very fine- to fine-grained and are similar in composition (Appendix B). Monocrystalline quartz is the dominant component in each sample (Appendix B), excluding the unusually high bioclastic component in Sample
146-893A-4H-6, 107-109 cm. It exhibits wavy to straight extinction and rare mineral inclusions. Sand-sized quartz crystals are also present as components of metaquartzite and polymineralic plutonic (e.g., quartz \pm plagioclase \pm muscovite) and metamorphic (e.g., quartz \pm phyllosilicate) rock fragments (Pl. 2). According to the Gazzi-Dickinson method of point counting, these sand-sized crystals within lithic fragments were counted as monocrystalline components. Feldspar is the second most important component, including plagioclase, potassium feldspar, and minor albite (unstained feldspar, totaled with plagioclase). These feldspar grains range from fresh to altered; micropitting, sericitization, and kaolinitization of these feldspar grains were most likely predepositional because of intrasample and intragrain variation in alteration.

Diverse lithic fragments are also present in Hole 893A sand (Pl. 2 ). Fine-grained metamorphic and sedimentary lithic fragments are relatively common, whereas volcanic lithic fragments are less common (Appendix B). The metamorphic lithic fragments include graphytic, sericitic (mica) and chloritic quartzose-schist fragments. Fine aggregates of quartz, feldspar, and mica are included in the metamorphic category; these are characteristic of gneissic to metasedimentary lithologies. A variety of sedimentary lithic fragments is found within the Hole 893A samples, including argillite/shale, siltstone, cherty argillite, micrite, and porcellanite or opaline chert fragments. Volcanic lithic fragments exhibiting vitric, felsitic, microlitic, lathwork, holocrystalline, and tuffaceous textures are relatively rare. Some volcanic fragments have fresh colorless to brown glassy groundmasses; however, most glassy fragments are devitrified and/or altered.

Opaque and nonopaque dense minerals are uncommon; the nonopaque fraction includes epidote, zoisite, brown and green amphibole, zircon, pyroxene, garnet, sphene, glaucophane(?), and apatite. Mica flakes are rare to common, with biotite predominating over muscovite; serpentine is rare. Bioclastic debris is predominantly intrabasinal calcareous foraminifers and shell fragments, with only minor siliceous (diatoms and sponge spicules) debris. The "other" category includes minor glauconite, phosphate, organic matter (plant debris and spores), and unknown grains. Coarse carbonate fragments probably are recycled veinfills or cements, or possibly authigenic precipitates within the sediments (e.g., Sample 146-893A-6H-4, 94 $95 \mathrm{~cm}$ ).

The diversity of dense minerals in Hole 893A samples is similar to that described in beach and stream samples from Santa Barbara coastal regions and the Santa Clara River by Rice et al. (1976). However, the relative percentage of dense minerals in the Hole 893A samples (Appendix B) is much less than that observed in coastal regions. This trend may be a simple function of grain size, with coarser beach and stream more enriched in dense minerals than finer basinal sand (Appendix B).

Sand from Hole 893A shows little variation in major-component (QFL and QmKP) detrital modes; it is quartzo-feldspathic with subequal amounts of quartz and feldspar grains (Fig. 3), and contains plagioclase and potassium feldspar (Fig. 4). There is more variation in lithic proportions, with samples generally containing subequal proportions of metamorphic, sedimentary, and volcanic lithic components (Fig. 5); this greater variability may be a function of the smaller total grain percentages represented by points on the lithic plot (see Appendix B). There is also a tendency for the finer-grained samples to be more enriched in plagioclase feldspar (Fig. 6), and some downhole changes in composition are apparent (Fig. 7).

\section{Beach and Stream Sand}

Beach and stream sand samples collected for this study range from fine to coarse, but are predominantly medium-grained (Appendix B). Grain types within these samples are similar to those found in Hole $893 \mathrm{~A}$ samples, except for a minor metavolcanic component (Appendix B). In general, beach and stream samples are either more quartzose or are enriched in lithic fragments (Figs. 3 and 4), and ex- 


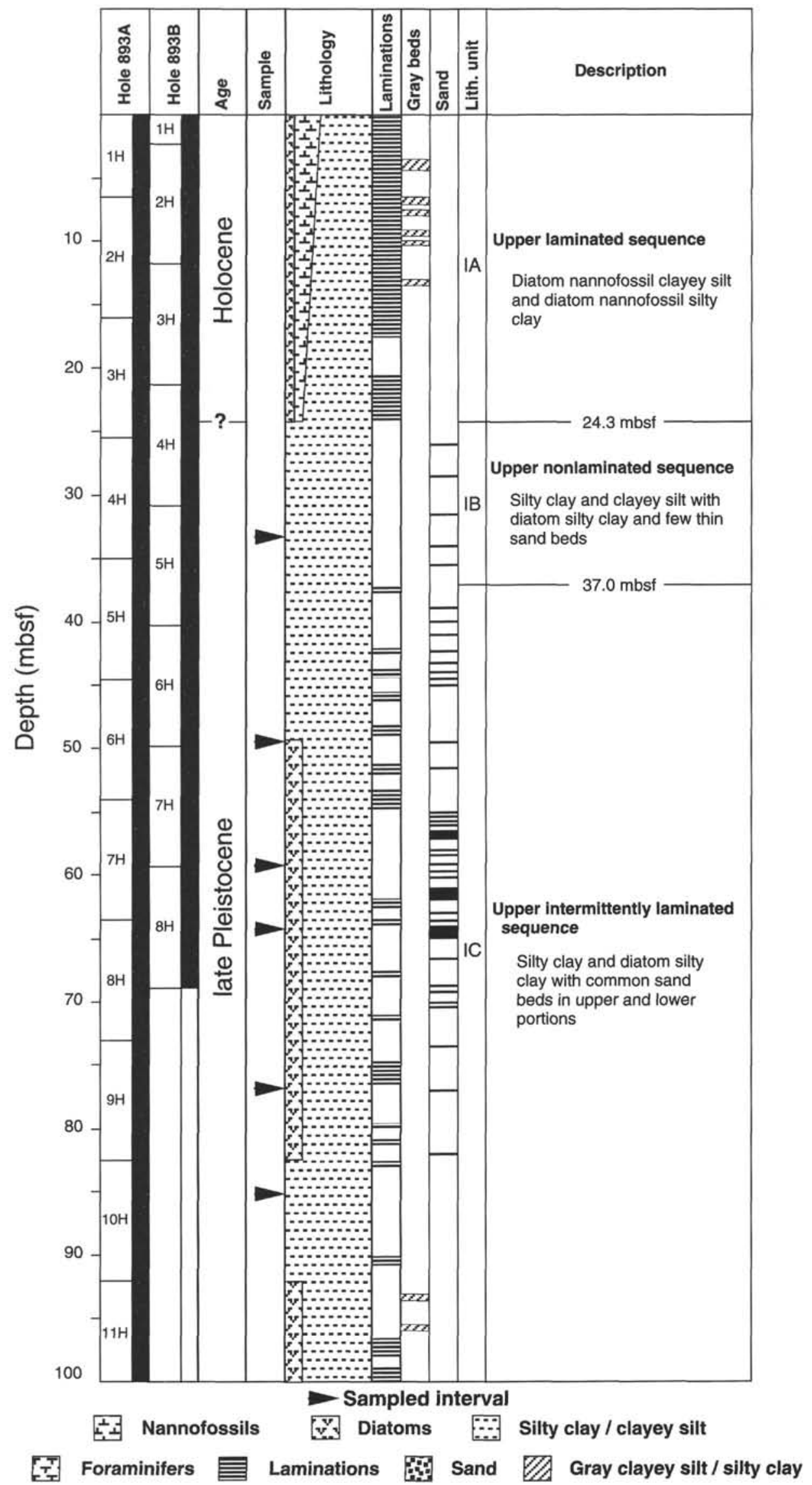

Figure 2. Lithologic summary chart for Site 893. Intervals sampled for this study are marked with arrows. Modified from Kennett, Baldauf, et al. (1994). 


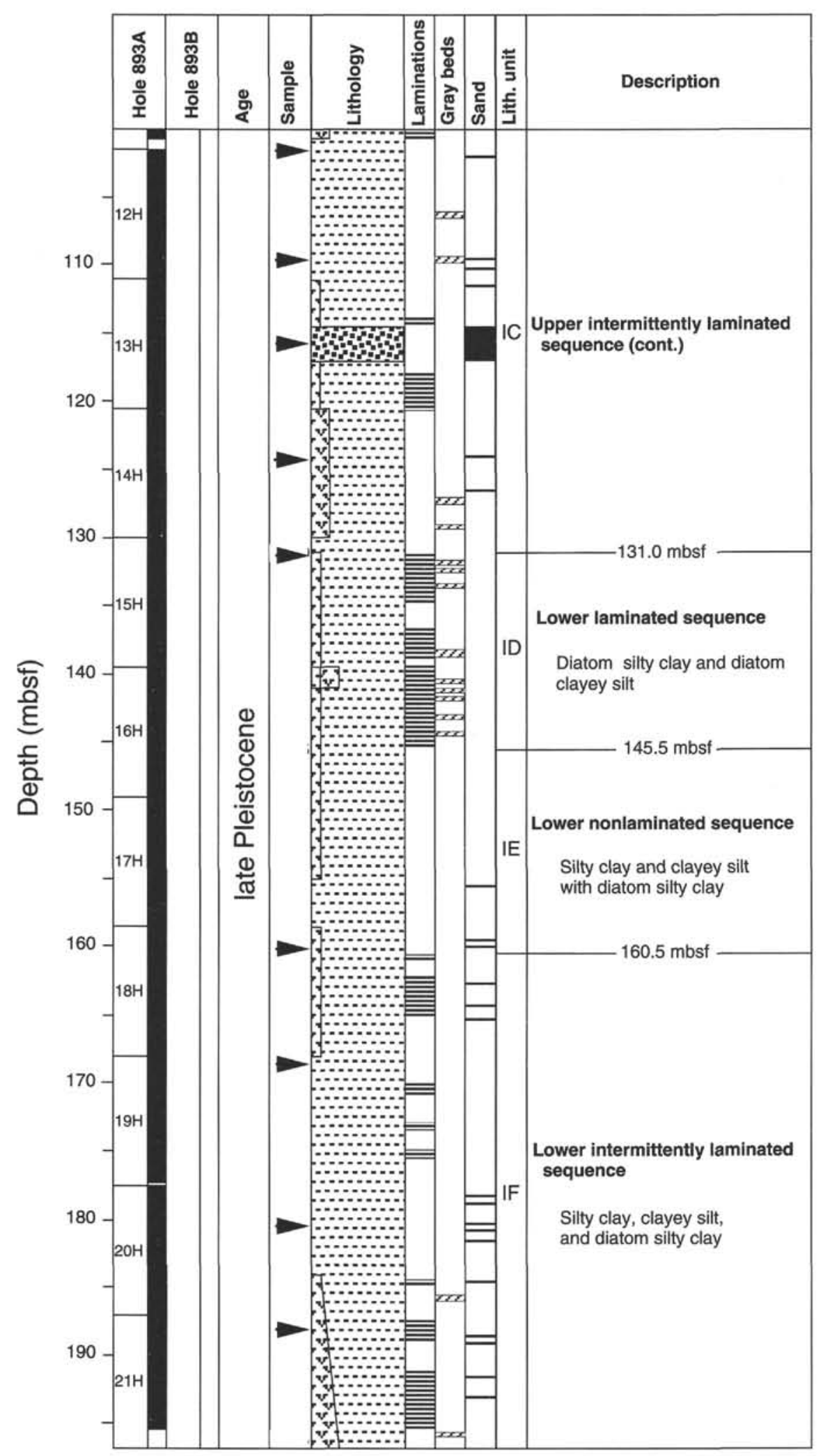

Figure 2 (continued). 


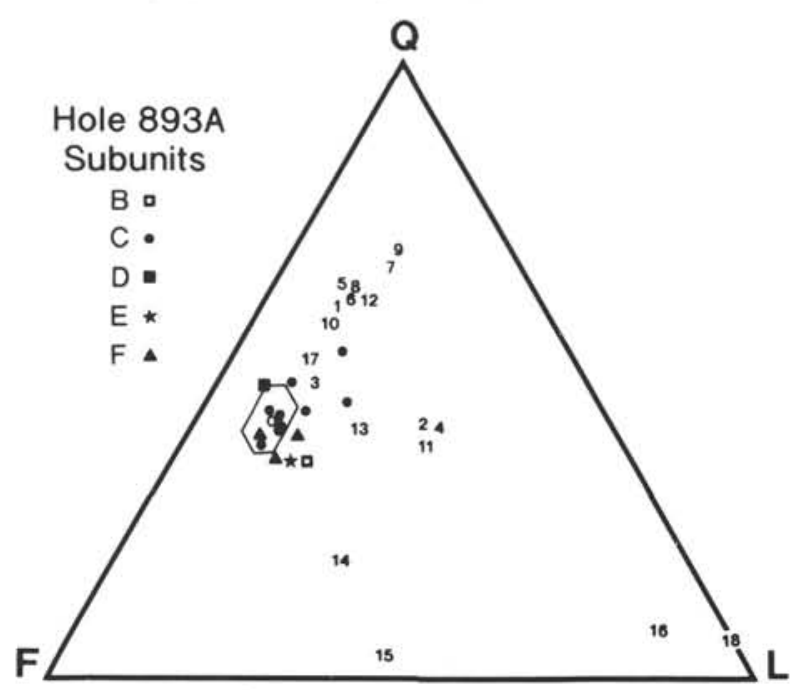

Figure 3. QFL ternary plot of Site 893 samples by subunit (IB through F). Composition of beach and stream samples are indicated by numbers 1 through 18. Mean $(\mathrm{O})$ and field of variation for seven Santa Clara River samples (Samples 116, 117, 118, 119, 122, 123, and 124) computed from data presented in Valles (1985). See Appendix A for definition of recalculated parameters and Appendix B for recalculated parameters.

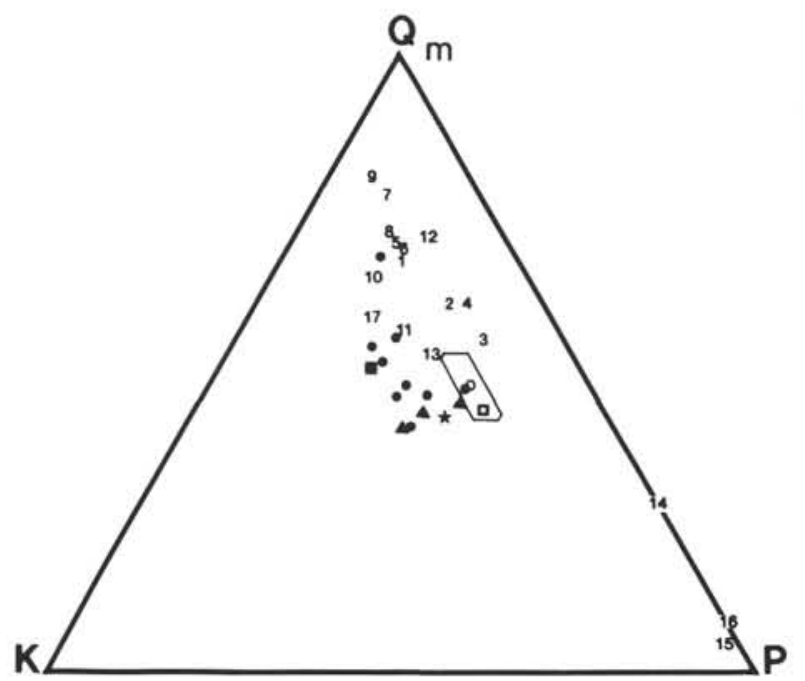

Figure 4. QmKP ternary plot of Site 893 samples by subunit (IB through F). Compositions of beach and stream samples are indicated by numbers 1 through 18. Mean $(\mathrm{O})$ and field of variation for seven Santa Clara River samples (Samples 116, 117, 118, 119, 122, 123, and 124) computed from data presented in Valles (1985). See Appendix A for definition of recalculated parameters and Appendix B for recalculated parameters.

hibit more variable lithic proportions than those from Hole 893A (Fig. 5).

\section{HOLE 893A SAND PROVENANCE}

Potential sources of the sand at Hole 893A exist at the northern, southern, and eastern margins of the basin. Sand associated with the northern margin is derived from coastal drainages along the Santa Ynez Mountains and from the Santa Ynez River via southward (and eastward) longshore transport around Point Conception. The eastern sand sources are the Ventura and Santa Clara rivers; the Channel Islands constitute the southern margin source. A study of clay mineralogy by Stein (this volume) indicates that the Santa Clara River is the predominant source for silt and clay at Site 893 . Based on relative

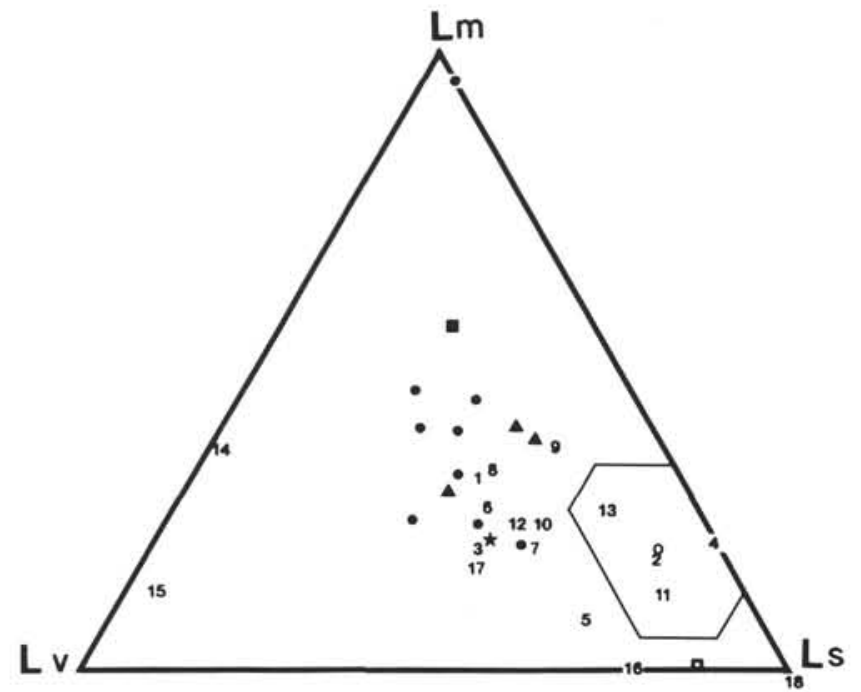

Figure 5. LmLvLs ternary plot of Site 893 samples by subunit (IB through F). Compositions of beach and stream samples are indicated by numbers 1 through 18. Mean $(\mathrm{O})$ and field of variation for seven Santa Clara River samples (Samples 116, 117, 118, 119, 122, 123, and 124) computed from data presented in Valles (1985). See Appendix A for definition of recalculated parameters and Appendix B for recalculated parameters.

drainage areas calculated by Fleischer (1972; Santa Clara River, 57\%; Santa Ynez River, 27\%; coastal drainage, $12 \%$; Ventura River, $7 \%$; and Channel Island drainage, $3 \%$ ), the most probable source of sand at Site 893 is also the eastern margin, followed by the northern and then southern margins. Each of the three possible source regions is evaluated and discussed below.

\section{Eastern Margin: Santa Clara and Ventura River Province}

The drainage basin of the Santa Clara River contains very diverse rock types, including granitic to anorthositic plutonic rocks, rhyodacitic to basaltic volcanic rocks, low- to high-grade metamorphic rocks, and numerous sedimentary units (Thomas et al., 1954; Fan, 1976; Jennings, 1977). These diverse source rocks are reflected in the composition of Santa Clara River sand (Fan, 1976; Ingersoll et al., 1993; Valles, 1985). Compositional variability is greatest within first-order stream samples, whereas second-order stream samples are more uniform (Ingersoll et al., 1993). For the purposes of this study, the composition of the downstream second-order stream samples analyzed by Valles (1985) are most useful, in that they most closely represent the sand dispersed into the Santa Barbara Basin. We calculated mean detrital modes for seven of these samples (Samples 116, 117, 118, 119 , 122,123 , and 124; Valles, 1985) collected from the lowermost reaches of the Santa Clara River; the means and fields of variation defined by standard deviations for this subset are shown in Figures 3, 4, and 5. These samples are quartzo-feldspathic (Fig. 3), with plagioclase dominant over potassium feldspar (Fig. 4), and a dominantly sedimentary lithic component (Fig. 5). Ingersoll et al. (1993) and Valles (1985) believe that they are composed predominantly of recycled sedimentary detritus. The sample of Santa Clara River sand analyzed for this study is similar in composition to samples collected by Valles (1985). Slight compositional variations could be attributed to storm history between the time Valles collected his samples (1983) and sample collection for this study (1993) or to the local compositional influence of tributary sediments. In general, samples from Hole 893A are similar to Santa Clara River sand in terms of their QFL percentages (Fig. 3), but on average they contain higher potassium feldspar (Fig. 4) and lower sedimentary-lithic proportions (Fig. 5)

Valles (1985) documented a downstream decrease in $\mathrm{P} / \mathrm{F}$ within the main Santa Clara stream channel from its headwaters to the Pa- 
Hole $893 \mathrm{~A}$ by subunit

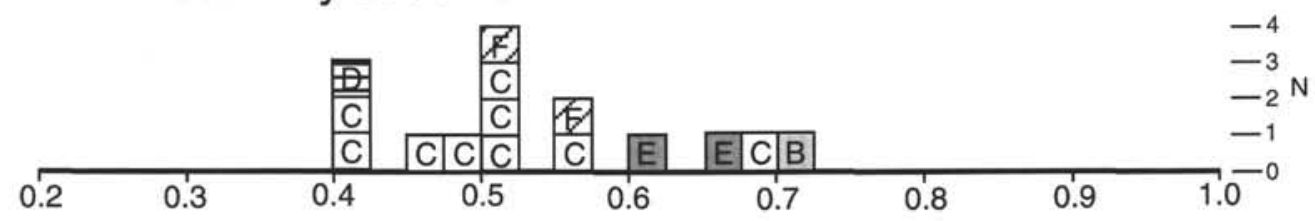

Hole $893 \mathrm{~A}$ by grain size

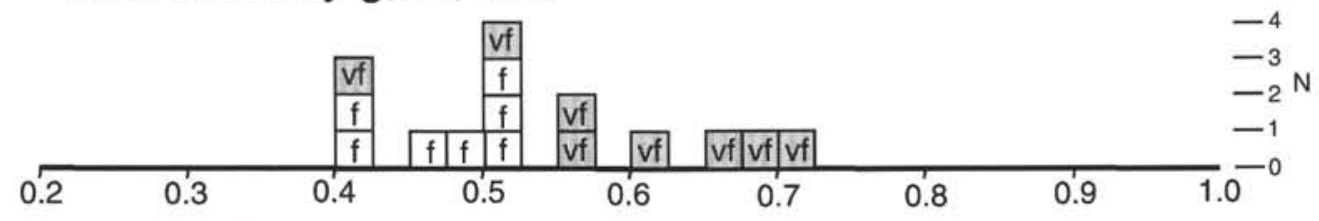

Beach and stream samples by location

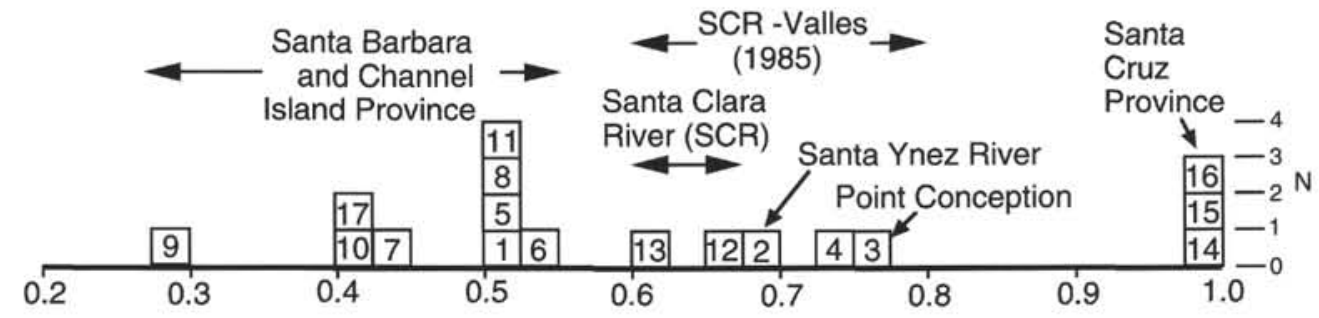

Beach and stream samples by grain size

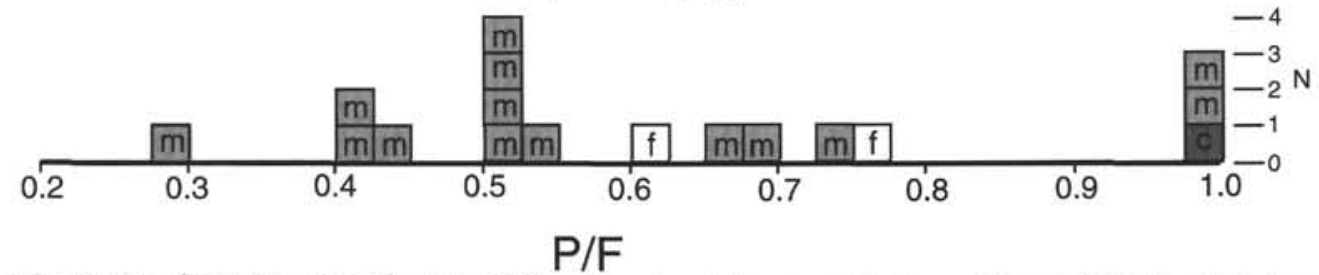

Figure 6. Histograms showing the distribution of P/F for Hole 893A and beach and stream samples (except Sample SSB-18, which does not contain feldspar). For sample locations, see Figure 1. See Appendix A for definition of recalculated parameters and Appendix B for recalculated parameters.

cific Ocean (Fig. 8). As the shoreline migrated seaward during the last glacial period, the Santa Clara River would have progressively lengthened. Valles' (1985) linear trend in P/F vs. downstream distance has been extended in Figure 8, and the modern shoreline and an estimated maximum paleoshoreline have been added. According to this model, the expected P/F for a lowstand Santa Clara River ranges from 0.44 to 0.63 , whereas the observed minimum P/F found in Subunits $1 \mathrm{C}$ and $1 \mathrm{~F}$ is less than this simple model predicts. An additional factor might be coastal drainage evolution and stream capture. Ventura River sand (Sample 11) has a significantly lower P/F (higher Kfeldspar content) than Santa Clara River sand; with only minor lowering of sea level, this stream most likely merged with the Santa Clara River, thus potentially decreasing the net P/F of the combined Santa Clara-Ventura drainage system.

The compositional effect of merging the Ventura and Santa Clara rivers on $\mathrm{P} / \mathrm{F}$ can be estimated using the relative discharges calculated by Fleischer (1972; Santa Clara River, 57\%; Santa Ynez River, 27\%; coastal drainage, $12 \%$; Ventura River, $7 \%$; and Channel Island drainage, $3 \%$ ) and measured $\mathrm{P} / \mathrm{F}$ from the rivers. We assume that the relative discharges are directly proportional to the volume of sand transported in each river. Given a P/F of 0.5 and relative discharge of $7 \%$ for the Ventura River, and a P/F of 0.62 and relative discharge of $57 \%$ for the Santa Clara River, the P/F of the mix of sand from these two rivers can be estimated at 0.60 . This 0.02 decrease in $\mathrm{P} / \mathrm{F}$ would produce a net effect of an additional $10 \mathrm{~km}$ of sediment transport on Figure 8. Thus, the lengthening of the Santa Clara River channel during sea-level fall and the addition of more potassium feldspar from the Ventura River could explain much of the P/F variability noted at Site 893 .

The additional transport distance associated with falling sea level might also decrease the proportion of less durable sedimentary lithic fragments. Compositional extremes in LmLvLs\%Lm are found within Subunits IB (low) and ID (high). Downhole trends in LmLvLs\%Ls could reflect subtle eustatic changes, tectonic effects, or climatic variations. An additional modification could have resulted from an influx of sand from the region around Sample 9 (Fig. 1); this sample is relatively enriched in metamorphic lithic fragments in comparison to the samples from the Santa Clara and Ventura rivers (Fig. $5)$.

\section{Northern Margin: Santa Barbara (Santa Ynez) Coastal Province}

The Santa Ynez Mountains form the northern margin of the Santa Barbara Basin. This range consists of Cretaceous through Miocene clastic sequences uplifted along the Santa Ynez Fault (Jennings, 


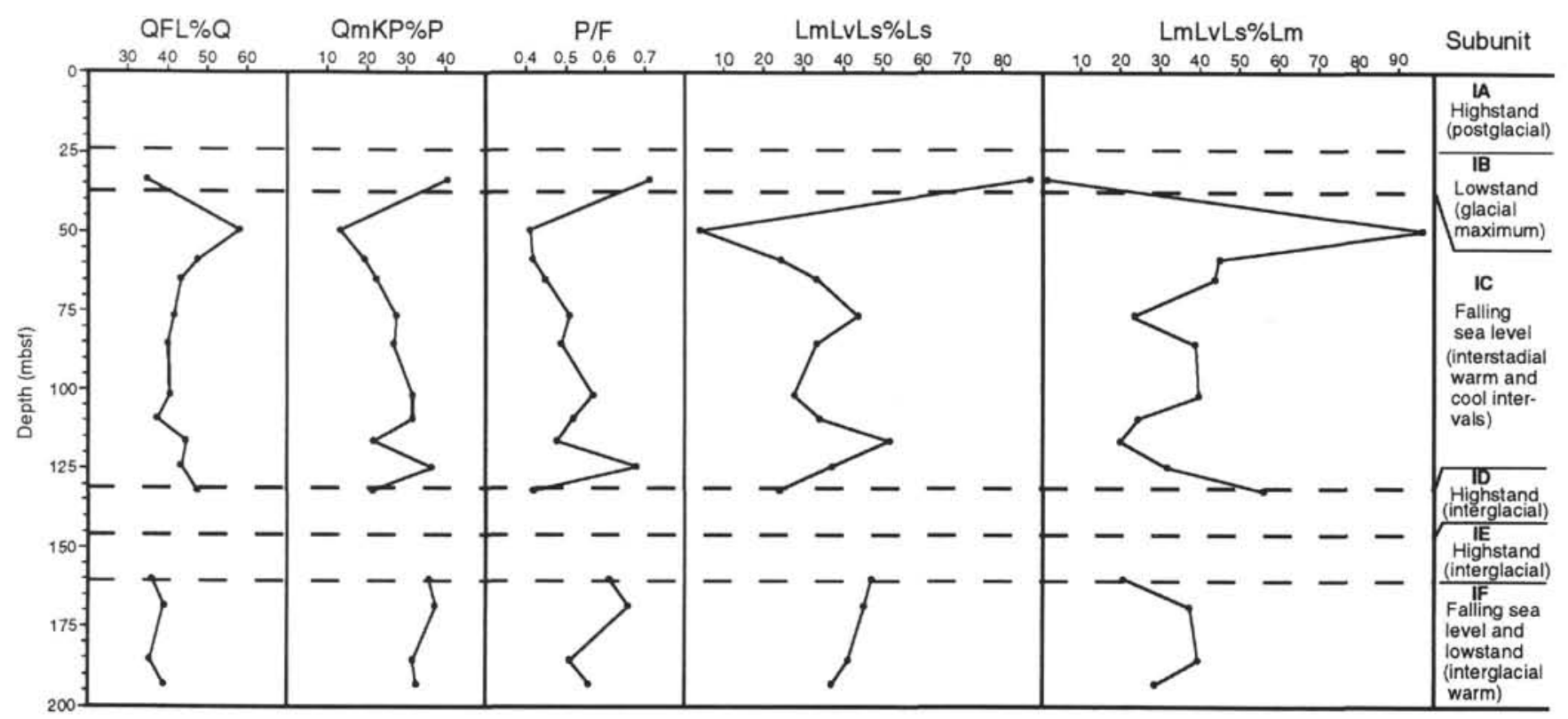

Figure 7. Downhole trends in sand detrital modes at Hole 893A.

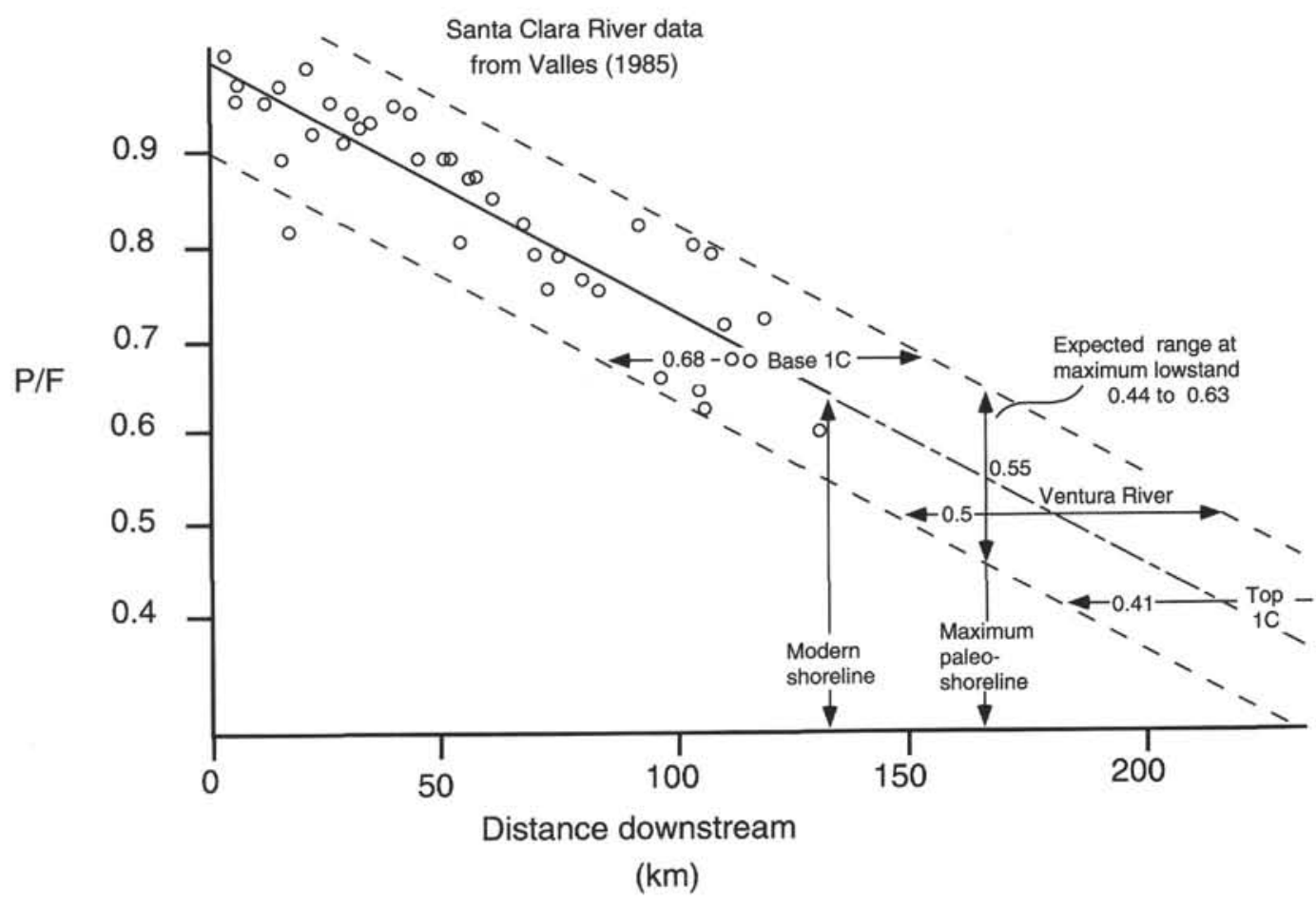

Figure 8. Plot of P/F vs. distance downstream for the Santa Clara River. Modified from Valles (1985). See Appendix A for definition of recalculated parameters and Appendix B for recalculated parameters.

1977). Miocene units occur along the now-submerged shelf (Vedder et al., 1986; McCulloch, 1989).

The relict Conception submarine fan (RCSF in Fig. 1) forms the gentle northwestern slope of the Santa Barbara Basin (Kraemer, 1987; Fischer et al., 1989). This fan formed during the Pleistocene and was abandoned $500 \mathrm{ka}$, when deformation and uplift in the Point Conception region resulted in a shift of sedimentation to the west and north into the Arguello Canyon system (Fischer 1972, 1976). According to Fisher (1976), some channels on this fan migrated to the northeast and remained active to the Holocene; they probably served as sources of fine-grained ( $\leq$ silt) sediment. Thus, this fan was not a likely source for the sand cored at Hole 893A.

On the modern inner shelf, sediment is finest in the Ventura region and coarsest to the west (Kolpack, 1986). Along the western part of the coast, between Santa Barbara and Point Conception, broad sand lobes extend across the shelf, whereas to the east, sand is confined primarily to a narrow coastal band (Kolpack, 1986). The thickest accumulations of Holocene sediment occur to the east, just north 
and south of Ventura ( $>50 \mathrm{~m}$ ), and to the west $(>30 \mathrm{~m}$ ) near sample locations 4 and 5 (Fig. 1; Kolpack, 1986); the former accumulations are associated with deltaic deposits and the latter with filled submarine canyons. Because these canyons project onto the Conception submarine fan, some of the sand at Site 893 may have been fed through these canyons during lowstands.

The composition of sand along the northern margin coastal areas is highly variable. In general, sand samples from this area are more quartzose than the Hole 893A samples (Figs. 3 and 4), but some of the coastal samples show LmLvLs proportions similar to those from Hole 893A (Samples 3, 6, 8, and 9; Fig. 5). A direct comparison between these beach and submarine sand samples is difficult because of the likely compositional modification associated with wave reworking (i.e., increase in \%Q). Because of this, some of the compositional differences could be attributed to differences in depositional environment. A northern source of Hole 893A sand cannot be ruled out, although we do not think it likely to be the dominant provenance.

\section{Southern Margin: Channel Islands Province}

The geology of the Channel Islands is somewhat more diverse than the Santa Barbara coastal region. Eocene to Miocene clastic sequences are exposed on Santa Rosa and San Miguel islands, whereas the core of Santa Cruz Island consists of schist and granite exposed along the Santa Cruz Island Fault, overlain by Tertiary volcanic and sedimentary sequences. The now-submerged offshore regions to the north of the islands are underlain dominantly by Miocene clastic sequences (Vedder et al., 1986; McCulloch, 1989). Beach samples were collected from Santa Cruz Island, the largest and most accessible of the three main Channel Islands, to define the nature of sediments shed from this province. It was thought that the provenance of sand derived from the primarily sedimentary sections on Santa Rosa Island and now-submerged shelf regions would likely be similar to that of the Santa Ynez Mountains.

The Santa Cruz Island samples are by far the most compositionally diverse suite of samples, perhaps directly a function of the small drainages represented by this sample suite. Sand samples (14 and 15) with primarily volcaniclastic provenance and sedimentary provenance (16 and 18) are compositionally distinct from other sands examined in this study, whereas one sample (17) from Santa Cruz Island with mixed provenance is similar to Hole 893A sand samples (Figs. 3-6). Thus, a major problem in determining the precise provenance of Hole 893A sand is the presence of similar Mesozoic to Cenozoic sedimentary units across the basin that, when weathered and eroded, produce sands with similar composition.

\section{DISCUSSION}

\section{Sand Provenance}

As outlined above, the chief source of sand at Hole 893A is most likely the Santa Clara and Ventura rivers on the eastern margin of the basin. The combined drainage area for these two rivers is several times that of the small streams that drain the Santa Ynez Mountains to the north and the Channel Islands to the south, and, consequently, the Santa Clara and Ventura rivers have the potential to supply the largest volume of sand to the basin. The wide distribution of Tertiary sedimentary rocks within the northern, eastern, and southern source regions, however, results in sources with similar, overlapping compositions. The lack of compositional uniqueness for sand shed from the basin margins precludes definitive source-area determinations for Hole 893A sand samples, but, as discussed below, the compositional trends observed within Subunit $1 \mathrm{C}$ are consistent with an eastern fluvial source (Santa Clara and Ventura rivers).

The composition of one sand sample at the base of Subunit 1B is distinct from that of the underlying sequence, suggesting that it may have had a significantly different source. This sample is also exceptional in that it is composed dominantly of bioclastic debris (Appendix B) and has the lowest QFL\%Q (34.9\%) of any Hole 893A samples, a value lower than many of the beach and stream samples. The high bioclastic component suggests that it is most probably a shelf or slope sand carried into the basin. The dearth of samples in this interval precludes any major conclusions as to the origin of this sediment. Given that it occurs in a section deposited during a lowstand, the closest shelf source would have been to the north, and the composition of this sample is consistent with derivation from the northern coastal regions.

\section{Stratigraphic Trends}

Stratigraphic trends in sand composition at Hole 893A are summarized in Figure 7. As data for Subunits 1B, 1D, and 1E are sparse and limited to subunit boundaries, we focus our discussion on the compositional trends between and within Subunits $1 \mathrm{C}$ and $\mathrm{IF}$.

There is less compositional variation in sand from Subunit IF than that from Subunit 1C. As indicated by the plot of QFL\%Q in Figure 7, there is a compositional break from Subunit $1 \mathrm{~F}$ across Subunits ID and IE associated with a shift to more quartzose compositions at the base of Subunit IC. This shift could be attributed to a change in the configuration of the source region after the IE and ID highstands; the magnitude of this shift in QFL\%Q (approximately $10 \%$ ) is not consistent with a major change in provenance over this interval. Apparent shifts in lithic and feldspar proportions across Subunits IE and ID are largely a function of one sample at the top of Subunit 1D (Fig. 7); if this sample is ignored, feldspar compositions are constant and lithic proportions are relatively similar from Subunit IF to Subunit IC.

Compositional trends within Subunit $\mathrm{IC}$ could be a function of (1) tectonic, (2) climatic, or (3) transport (depositional) factors. Most components show a gradual shift in composition across the interval from 45 to $80 \mathrm{~m}$ below seafloor (mbsf) at the top of the subunit, whereas less consistent variations occur in the lower part.

\section{Tectonic Influence}

Faults within the onshore Ventura Basin and adjacent highlands have been active during the last $200,000 \mathrm{yr}$ (Yeats, 1983), but a detailed history of the tectonic activity that might have produced the observed compositional trends in Subunit $\mathrm{IC}$ has not been defined. Periods of intense tectonic activity could be tied to increases in sand input to the basin. However, compositional trends do not correlate with trends in the percentage of sand within the section as outlined by Behl (this volume; maxima occur at 56-70, 108-115, and 170 mbsf) and sand composition does not directly relate to bed thickness (Appendix B).

\section{Climatic Influence}

Compositional trends outlined in Figure 7 do not correspond to the oxygen isotope curve of Kennett (this volume), which reflects relative sea-level changes, or to the pollen data of Heusser (this volume), which reflect changes in climate and precipitation. Climatic variations were perhaps not sufficiently extreme during the late Quaternary to result in significant weathering effects on composition; Heusser (this volume) estimated onshore temperature variations of $4^{\circ} \mathrm{C}$ and rainfall variations of $20 \mathrm{~cm} / \mathrm{yr}$ between glacial and interglacial periods.

\section{Transport Influence}

The gradational trend at the top of Subunit IC (80-45 mbsf) would best be ascribed to an evolutionary change in the source region, and, as discussed above, most probably an increase in stream 
length associated with falling sea level and the merging of drainages (Fig. 8). Stratigraphic changes in LmLvLs\%Ls could be attributed to variations in tectonism and rates of uplift and erosion of sedimentary sections within the basin.

\section{CONCLUSIONS}

During the last $160 \mathrm{ka}$, there have been two main pulses of coarse clastic sediment into the Santa Barbara Basin associated with falling sea level, as represented by Subunits IC and IF at Hole 893A. The detrital modes of sand recovered at Hole $893 \mathrm{~A}$ suggest that the most likely source of this sand was a combination of the Santa Clara and Ventura rivers along the eastern margin of the Santa Barbara Basin. Gradational changes in composition observed at the top of Subunit IC probably reflect evolutionary changes within the drainage basin, associated with the lengthening and expansion of the river system as sea level dropped and shelf areas were exposed.

Overall, petrographic data for Hole 893A cluster rather tightly on standard QFL and QmKP compositional plots (Figs. 3 and 4), but values are much more diverse in terms of lithic proportions (Fig. 5). The lithic proportions appear to vary considerably within and between subunits; trends within Subunit IC sedimentary lithic proportions could reflect small-scale eustatic cycles (shoreline migrations) or tectonic cycles (uplift rates) within depositional systems or source areas.

\section{ACKNOWLEDGMENTS}

RJB was supported by a postdoctoral fellowship at the Marine Science Institute, University of California, Santa Barbara, and KCR was supported by a DOE fellowship administered by CERM at the University of Texas at El Paso while working on this project. Thanks to Gary Girty and Raymond Ingersoll for their thoughtful reviews, and to Raymond Ingersoll for providing a copy of Peter Valles' thesis. This paper is dedicated to the memory of Barbara Marsaglia.

\section{REFERENCES}

Dickinson, W.R., 1970. Interpreting detrital modes of graywacke and arkose. J. Sediment. Petrol., 40:695-707.

Drake, D.E., Kolpack, R.L., and Fischer, P.J., 1972. Sediment transport on the Santa Barbara-Oxnard shelf, Santa Barbara Channel, California. In Swift, D.J.P., Duane, D.B., and Pilkey, O.H. (Eds.), Shelf Sediment Transport: Stroudsburg, PA (Dowden, Hutchinson, and Ross), 307-331.

Fan, P., 1976. Recent silts in the Santa Clara River drainage basin, Southern California: a mineralogical investigation of their origin and evolution. $J$. Sediment. Petrol., 46:802-812.

Fischer, P.J., 1972. Geologic evolution and Quaternary geology of the Santa Barbara Basin, Southern California [Ph.D. dissert.]. Univ. Southern Calif., Los Angeles.

, 1976. Late Neogene-Quaternary tectonics and depositional environments of the Santa Barbara Basin, California. In Fritsche, A.E., Ter Best, H., Jr., and Wornardt, W.W. (Eds.), The Neogene Symposium. Spec. Pub.-Soc. Econ. Paleont. Min., Pac. Sect., 33-52.

Fischer, P.J., Thor, D.R., and Cherven, V.B., 1989. Anatomy of Quaternary Conception Submarine Fan, Santa Barbara Basin, California. AAPG Bull., 73:538. (Abstract)

Fleischer, P., 1972. Mineralogy and sedimentation history, Santa Barbara Basin, California. J. Sediment. Petrol., 42:49-58.

Gorsline, D.S., Nardin, T.R., Edwards, B.D., Drake, D.E., Thornton, S.E., and Day, P.C., 1982. Influence of current scour on basin sills: Anacapa Passage, California Borderland. Geol. Soc. Am. Abstr. Progr., 14:500. (Abstract)

Hülsemann, J., and Emery, K.O., 1961. Stratification in recent sediments of Santa Barbara Basin as controlled by organisms and water character. $J$. Geol., 69:279-290.

Ingersoll, R.V., Bullard, T.F., Ford, R.L., Grimm, J.P., Pickle, J.D., and Sares, S.W., 1984. The effect of grain size on detrital modes: a test of the Gazzi-Dickinson point-counting method. J. Sediment. Petrol., 54:103116.
Ingersoll, R.V., Kretchmer, A.G., and Valles, P.K., 1993. The effect of sampling scale on actualistic sandstone petrofacies. Sedimentology, 40:937953.

Ingle, J.C., Jr., 1980. Cenozoic paleobathymetry and depositional history of selected sequences within the southern California continental borderland. In Sliter, W.V. (Ed.), Studies in Marine Micropaleontology and Paleoecology: A Memorial to Orville L. Bandy. Spec. Publ. Cushman Found. Foraminiferal Res., 19:163-195.

Jennings, C.W., 1977. Geologic Map of California: Geologic Data Map No. 2: Sacramento (Calif. Div. Mines Geol.). Scale 1:750,000.

Kennett, J.P., Baldauf, J.G., et al., 1994. Proc. ODP, Init. Repts., 146 (Pt. 2): College Station, TX (Ocean Drilling Program).

Kolpack, R.L.. 1986. Sedimentology of the mainland nearshore region of Santa Barbara Channel, California. In Knight, R.J., and McLean, J.R. (Eds.), Shelf Sands and Sandstones. Mem. - Can. Soc. Pet. Geol., 11:5772 .

Kraemer, S.M.C., 1987. Quaternary Conception fan, Santa Barbara, California. AAPG Bull., 71:578. (Abstract)

Marsaglia, K.M., and Tazaki, K., 1992. Diagenetic trends in Leg 126 sandstones. In Taylor, B., Fujioka, K., et al., Proc. ODP. Sci. Results, 126: College Station, TX (Ocean Drilling Program), 125-138.

McCulloch. D.S., 1989. Geologic map of the south-central California continental margin. In Greene, H.G., and Kennedy, M.P. (Eds.), Geology of the Mid-southern California Continental Margin, Calif. Contin. Margin Geologic Map Ser., Map 4A. Sacramento (Calif. Div. Mines Geol.). Scale 1:250,000.

Reed, R.D., and Hollister, J.S., 1936. Structural evolution of southern California. AAPG Bull., 20:1529-1704.

Rice, R.M., Gorsline, D.S., and Osborne, R.H., 1976. Relationship between sand input from rivers and the composition of sands from the beaches of Southern California. Sedimentology, 23:689-703.

Schimmelmann, A., Lange, C.B., Berger, W.H., Simon, A., Burke, S.K., and Dunbar, R.B., 1992. Extreme climatic conditions recorded in Santa Barbara Basin laminated sediments: the 1835-1840 Macoma event. Mar. Geol., 106:279-299.

Shaw, J.H., and Suppe, J., 1994. Active faulting and growth faulting in the eastern Santa Barbara Channel, California. Geol. Soc. Am. Bull., $106: 607-626$

Shore-based Scientific Party, 1994. Site 893. In Kennett, J.P., Baldauf, J.G., et al., Proc, ODP, Init. Repts., 146 (Pt. 2): College Station, TX (Ocean Drilling Program), 15-81.

Soutar, A., and Crill, P.A., 1977. Sedimentation and climatic patterns in the Santa Barbara Basin during the 19th and 20th centuries. Geol. Soc. Am. Bull., 88:1161-1172.

Thomas, R.G., Marliave, E.C., James, C.B., and Bean, R.T., 1954. Geology and hydrology of Ventura County. Bull.-Calif. Div. Mines Geol., 170:19-28.

Thornton, S.E., 1981. Holocene stratigraphy and sedimentary processes in Santa Barbara Basin: influence of tectonics, ocean circulation, climate and mass movement [Ph.D. dissert.]. Univ. Southern Calif., Los Angeles. , 1984. Basin model for hemipelagic sedimentation in a tectonically active continental margin: Santa Barbara Basin, California continental borderland. In Stow, D.A.V., and Piper, D.J.W. (Eds.), Finegrained Sediments: Deep-water Processes and Facies. Geol. Soc. Spec. Publ. London, 15:377-394.

Trask, P.D., 1952. Source of beach sand at Santa Barbara, California as indicated by mineral grain studies. Univ. Calif. Tech. Rep. Eng., Ser. 14, no. 11.

Valles, P.K., 1985. Sand composition of the Santa Clara River, California: implications for tectonic setting [M.S. thesis]. Univ. Calif., Los Angeles.

Vedder, J.G., Greene, H.G., Clarke, S.H., and Kennedy, M.P., 1986. Geologic map of the mid-southern California continental margin. In Greene, H.G., and Kennedy, M.P. (Eds.), Geology of the Mid-southern California Continental Margin, Calif. Contin. Margin Geologic Map Ser., Map 2A. Sacramento (Calif. Div. Mines Geol.). Scale 1:250,000.

Vedder, J.G., Wagner, H.C., and Schoellhamer, J.E., 1969. Geological framework of the Santa Barbara channel region. In Geology, Petroleum Development and Seismicity of the Santa Barbara Channel Region, California. Geol. Surv. Prof. Pap. U.S., 679A:1-11.

Yeats, R.S., 1983. Large-scale Quaternary detachments in Ventura Basin, southern California. J. Geophys. Res., 88:569-583.

Date of initial receipt: 1 September 1994

Date of acceptance: 19 January 1995

Ms 146SR-274 
APPENDIX A

Counted and Recalculated Parameters

\begin{tabular}{|c|c|c|}
\hline \multicolumn{3}{|c|}{ Counted and Recalculated Parameters } \\
\hline \multicolumn{3}{|c|}{ Counted parameters: } \\
\hline Qp: & \multicolumn{2}{|l|}{ Polycrystalline quartz } \\
\hline Qm: & \multicolumn{2}{|l|}{ Monocrystalline quartz } \\
\hline P: & \multicolumn{2}{|l|}{ Plagioclase feldspar } \\
\hline $\mathrm{K}:$ & \multicolumn{2}{|l|}{ Potassium feldspar } \\
\hline Fu: & \multicolumn{2}{|l|}{ Unstained (Na?) feldspar } \\
\hline Lvo: & \multicolumn{2}{|c|}{ Other volcanic lithic (microcrystalline aggregate) } \\
\hline Lvv: & \multicolumn{2}{|l|}{ Vitric volcanic lithic } \\
\hline Lvml: & \multicolumn{2}{|c|}{ Volcanic lithic with microlitic texture } \\
\hline Lvl: & \multicolumn{2}{|c|}{ Volcanic lithic with lathwork texture } \\
\hline Lvf: & \multicolumn{2}{|c|}{ Volcanic lithic with felsitic texture } \\
\hline Lvp: & \multicolumn{2}{|l|}{ Pyroclastic lithic } \\
\hline Lmv: & \multicolumn{2}{|l|}{ Metavolcanic lithic } \\
\hline Lmm: & \multicolumn{2}{|l|}{ Polycrystalline mica lithic } \\
\hline Lmt: & \multicolumn{2}{|l|}{ Quartz-mica tectonite lithic } \\
\hline Lma: & \multicolumn{2}{|c|}{ Quartz-feldspar-mica aggregate lithic } \\
\hline Lsa: & \multicolumn{2}{|c|}{ Argillite-shale lithic } \\
\hline Lsc: & \multicolumn{2}{|l|}{ Sedimentary carbonate lithic } \\
\hline Lsi: & \multirow{2}{*}{\multicolumn{2}{|c|}{$\begin{array}{l}\text { Siltstone or sandstone (matrix/cement) sedimentary lithic } \\
\text { Sedimentary chert or cherty arcillite lithic }\end{array}$}} \\
\hline Lsch: & & \\
\hline Lso: & \multicolumn{2}{|c|}{$\begin{array}{l}\text { Sedimentary chert or cherty argillite lithic } \\
\text { Other sedimentary lithic }\end{array}$} \\
\hline M: & \multicolumn{2}{|l|}{ Mica } \\
\hline Do: & \multicolumn{2}{|l|}{ Opaque dense minerals } \\
\hline Dn: & \multicolumn{2}{|l|}{ Nonopaque dense minerals } \\
\hline S: & \multicolumn{2}{|l|}{ Serpentine } \\
\hline & \multicolumn{2}{|l|}{ Carbonate minerals } \\
\hline Bio: & \multirow{2}{*}{\multicolumn{2}{|c|}{ Bioclastic debris }} \\
\hline Other: & \multirow{2}{*}{\multicolumn{2}{|c|}{$\begin{array}{l}\text { Other miscellaneous and unidentified grains } \\
\text { Total points counted }\end{array}$}} \\
\hline Total: & & \\
\hline $\begin{array}{l}\mathrm{Q}=\mathrm{Qm} \\
\mathrm{F}=\mathrm{P}+\mathrm{K} \\
\mathrm{L}=\mathrm{Lm}+ \\
\mathrm{Lv}=\mathrm{Lvo} \\
\mathrm{Lm}=\mathrm{Lm} \\
\mathrm{Ls}=\mathrm{Lsa}\end{array}$ & $\begin{array}{l}\text { Qp } \\
+\mathrm{Fu} \\
\mathrm{Lv}+\mathrm{Ls} \\
+\mathrm{Lvv}+\mathrm{Lvf}+\mathrm{Lvmi}+\mathrm{LvI}+\mathrm{L} \\
v+\mathrm{Lmm}+\mathrm{Lmt}+\mathrm{Lma} \\
+\mathrm{Lsc}+\mathrm{Lsi}+\mathrm{Lsch}+\mathrm{Lso}\end{array}$ & \\
\hline Recalcula & ted parameters: & \\
\hline QFL\% & $\mathrm{Q}=100^{*} \mathrm{Q} /(\mathrm{Q}+\mathrm{F}+\mathrm{L})$ & $\mathrm{LmLvLs} \% \mathrm{Lm}=100^{*} \mathrm{Lm} / \mathrm{L}$ \\
\hline QFL\% & $=100^{*} \mathrm{~F} /(\mathrm{Q}+\mathrm{F}+\mathrm{L})$ & $\mathrm{LmLvLs} \% \mathrm{Lv}=100^{*} \mathrm{Lv} / \mathrm{L}$ \\
\hline QFL\% & $=100 * \mathrm{~L} /(\mathrm{Q}+\mathrm{F}+\mathrm{L})$ & LmLvLs\%Ls $=100^{*} \mathrm{Ls} / \mathrm{L}$ \\
\hline QmKP & $6 \mathrm{Qm}=100 * \mathrm{Qm} /(\mathrm{Qm}+\mathrm{F})$ & \\
\hline QmKP & $R P=100 *(\mathrm{P}+\mathrm{Fu}) /(\mathrm{Qm}+\mathrm{F})$ & \\
\hline QmKP & $\% \mathrm{~K}=100 * \mathrm{~K} /(\mathrm{Qm}+\mathrm{F})$ & \\
\hline
\end{tabular}


APPENDIX B

Hole 893A Petrographic Data

\begin{tabular}{|c|c|c|c|c|c|c|c|c|c|c|c|c|c|c|c|c|c|c|c|}
\hline $\begin{array}{l}\text { Core, section, } \\
\text { interval }(\mathrm{cm})\end{array}$ & $\begin{array}{l}\text { Depth } \\
\text { (mbsf) }\end{array}$ & $\begin{array}{l}\text { Age } \\
\text { (ka) }\end{array}$ & Subunit & $\begin{array}{l}\text { Grain } \\
\text { size }\end{array}$ & Bed size & Qp & Qm & $P$ & K & $\mathrm{Fu}$ & Lvo & Lvv & Lvml & Lvl & Lvf & Lvp & Lmv & Lmm & Lmt \\
\hline $4 \mathrm{H}-6,107-108$ & 33.24 & 21.569 & IB & vf & Thin & 1 & 43 & 40 & 17 & 1 & 0 & 2 & 1 & 0 & 0 & 0 & 0 & 0 & 0 \\
\hline $6 \mathrm{H}-4,94-95$ & 49.13 & 33.184 & IC & $v f$ & Thin & 7 & 186 & 36 & 53 & I & 0 & 0 & 0 & 0 & 0 & 0 & 0 & 20 & 27 \\
\hline $7 \mathrm{H}-5,129-130$ & 58.85 & 40.178 & IC & $f$ & Thick & 4 & 133 & 49 & 69 & 0 & 2 & 0 & 1 & 0 & 7 & 0 & 0 & 2 & 8 \\
\hline $8 \mathrm{H}-2,89-90$ & 64.54 & 44.272 & IC & $f$ & Thick & 3 & 165 & 72 & 91 & 1 & 0 & 5 & 1 & 0 & 6 & I & 0 & 4 & 12 \\
\hline $9 \mathrm{H}-3,134-135$ & 76.64 & 53.319 & IC & f & Thin & 4 & 120 & 71 & 67 & 0 & 0 & 0 & 2 & 1 & 8 & 0 & 0 & 2 & 1 \\
\hline $10 \mathrm{H}-2,140-141$ & 85.26 & 60.589 & 1C & f & Thin & 4 & 110 & 66 & 69 & 0 & 0 & 3 & 2 & 0 & 5 & 0 & 0 & 2 & 10 \\
\hline $12 \mathrm{H}-\mathrm{I}, 27-28$ & 101.77 & 77.053 & IC & vf & Thin & 7 & 136 & 94 & 71 & 2 & 1 & 6 & 2 & 2 & 3 & 0 & 0 & 6 & 6 \\
\hline $12 \mathrm{H}-7,22-23$ & 109.17 & 84.96 & IC & f & Thin & 14 & 126 & 99 & 92 & 2 & 0 & 4 & 5 & 2 & 6 & 0 & 0 & 1 & 4 \\
\hline $13 \mathrm{H}-5,77-78$ & 115.86 & 90.003 & IC & $f$ & Thick & 9 & 164 & 61 & 72 & 5 & 0 & 4 & 3 & 2 & 12 & 0 & 0 & 2 & 9 \\
\hline $14 \mathrm{H}-3,67-68$ & 124.23 & 98.416 & IC & vf & Thin & 9 & 152 & 113 & 57 & 6 & 1 & 1 & 3 & 0 & 6 & 0 & 0 & 4 & 5 \\
\hline $15 \mathrm{H}-2,73-74$ & 131.92 & 106.632 & ID & $\mathrm{f}$ & Thin & 6 & 164 & 70 & 95 & 0 & i & 0 & 0 & 0 & 4 & 0 & 0 & 4 & 8 \\
\hline $18 \mathrm{H}-2,8-9$ & 160.03 & 129.846 & IE & vf & Thin & 6 & 119 & 103 & 66 & 0 & 0 & 8 & 2 & 0 & 7 & 0 & 0 & 4 & 6 \\
\hline $19 \mathrm{H}-1.44-45$ & 168.42 & 137.402 & IF & vf & Thick & 12 & 120 & 99 & 53 & 3 & 0 & 3 & 1 & 1 & 4 & 0 & 0 & 5 & 11 \\
\hline $20 \mathrm{H}-3,14-15$ & 180.48 & 148.263 & IF & $\mathrm{vf}$ & Thin & 9 & 118 & 89 & 89 & 3 & 0 & 3 & 1 & 0 & 6 & 0 & 0 & 9 & 10 \\
\hline $21 \mathrm{H}-2,6-7$ & 187.98 & 155.018 & IF & vf & Thin & 7 & 127 & 97 & 77 & 1 & 0 & 3 & 0 & 0 & 9 & 0 & 0 & 2 & 6 \\
\hline
\end{tabular}

\begin{tabular}{|c|c|c|c|c|c|c|c|c|c|c|c|c|c|c|c|c|c|c|c|}
\hline $\begin{array}{l}\text { Core, section, } \\
\text { interval }(\mathrm{cm})\end{array}$ & $\begin{array}{l}\text { Depth } \\
\text { (mbsf) }\end{array}$ & $\begin{array}{l}\text { Age } \\
\text { (ka) }\end{array}$ & Subunit & $\begin{array}{c}\text { Grain } \\
\text { size }\end{array}$ & Bed size & Lma & Lsa & Lsc & Lsi & Lsch & Lso & M & Do & Dn & $\mathrm{S}$ & $\mathrm{C}$ & Bio & Other & Total \\
\hline $4 \mathrm{H}-6,107-108$ & 33.24 & 21.569 & 1B & $\mathrm{vf}$ & Thin & 0 & 7 & 14 & 0 & 0 & 0 & 11 & 1 & 2 & 0 & 0 & 256 & 4 & 400 \\
\hline $6 \mathrm{H}-4,94-95$ & 49.13 & 33.184 & IC & vf & Thin & I & 2 & 0 & 0 & 0 & 0 & 22 & 1 & 5 & 0 & 15 & 22 & 2 & 400 \\
\hline $7 \mathrm{H}-5,129-130$ & 58.85 & 40.178 & IC & $\mathrm{f}$ & Thick & 5 & 8 & 0 & 0 & 0 & 0 & 7 & i & 0 & 0 & 3 & 1 & 0 & 300 \\
\hline $8 \mathrm{H}-2,89-90$ & 64.54 & 44.272 & IC & f & Thick & 9 & 6 & 1 & 4 & 4 & 4 & 2 & 2 & 2 & 0 & 2 & 3 & 0 & 400 \\
\hline $9 \mathrm{H}-3,134-135$ & 76.64 & 53.319 & ic & $\mathrm{f}$ & Thin & 5 & 8 & 0 & 0 & 0 & 7 & 2 & 0 & 0 & 0 & 0 & 2 & 0 & 300 \\
\hline $10 \mathrm{H}-2,140-141$ & 85.26 & 60.589 & IC & $f$ & Thin & 2 & 10 & 0 & 0 & 2 & 0 & 6 & 0 & 2 & 0 & 0 & 6 & 1 & 300 \\
\hline $12 \mathrm{H}-\mathrm{I}, 27-28$ & 101.77 & 77.053 & IC & vf & Thin & 5 & iI & 0 & 0 & 0 & I & 13 & 2 & 3 & 0 & 2 & 9 & 18 & 400 \\
\hline $12 \mathrm{H}-7,22-23$ & 109.17 & 84.96 & IC & f & Thin & 5 & 6 & 0 & 0 & 0 & 8 & 5 & 0 & 2 & 0 & i & 4 & 14 & 400 \\
\hline $13 \mathrm{H}-5,77-78$ & 115.86 & 90.003 & IC & $f$ & Thick & 4 & 25 & 2 & 3 & 2 & 7 & 8 & 2 & 0 & 0 & 2 & 2 & 0 & 400 \\
\hline $14 \mathrm{H}-3,67-68$ & 124.23 & 98.416 & ic & vf & Thin & 2 & 8 & $i$ & 3 & i & 0 & 1 & 3 & 8 & 0 & 0 & 1 & 15 & 400 \\
\hline $15 \mathrm{H}-2,73-74$ & 131.92 & 106.632 & ID & $f$ & Thin & 2 & 5 & 0 & 0 & I & 0 & 5 & 3 & 4 & 1 & 4 & 9 & 14 & 400 \\
\hline $18 \mathrm{H}-2,8-9$ & 160.03 & 129.846 & IE & vf & Thin & $i$ & 19 & 3 & 0 & i & 2 & 15 & 4 & 6 & 0 & 3 & 22 & 3 & 400 \\
\hline $19 \mathrm{H}-\mathrm{I}, 44-45$ & 168.42 & 137.402 & IF & $\mathrm{vf}$ & Thick & 3 & 14 & 2 & 1 & 3 & 3 & 22 & 4 & 2 & 0 & 4 & 14 & 16 & 400 \\
\hline $20 \mathrm{H}-3,14-15$ & 180.48 & 148.263 & IF & vf & Thin & 1 & 14 & 0 & i & 6 & 0 & 8 & 1 & 12 & 0 & 1 & 14 & 5 & 400 \\
\hline $21 \mathrm{H}-2,6-7$ & 187.98 & 155.018 & IF & vf & Thin & 2 & 10 & 3 & 0 & 0 & 0 & 10 & $\mathrm{i}$ & 6 & 0 & 5 & 33 & 1 & 400 \\
\hline
\end{tabular}

\begin{tabular}{|c|c|c|c|c|c|c|c|c|c|c|}
\hline $\begin{array}{l}\text { Core, section, } \\
\text { interval }(\mathrm{cm})\end{array}$ & QFL\%Q & QFL\%F & QFL\%L & QmKP\%Qm & QmKP\%K & QmKP\%P & LmLvLs\%Lm & LmLvLs\%Lv & LmLvLs\%Ls & $\mathrm{P} / \mathrm{F}$ \\
\hline $4 \mathrm{H}-6,107-108$ & 34.9 & 46 & 19 & 42.6 & 16.8 & 40.6 & 0 & 12.5 & 87.5 & 0.71 \\
\hline $6 \mathrm{H}-4,94-95$ & 58 & 27 & 15 & 67.4 & 19.2 & 13.4 & 96 & 0 & 4 & 0.41 \\
\hline $7 \mathrm{H}-5,129-130$ & 47.6 & 41 & 11.5 & 53 & 27.5 & 19.5 & 45.5 & 30.3 & 24.2 & 0.42 \\
\hline $8 \mathrm{H}-2,89-90$ & 43.2 & 42.2 & 14.7 & 50.2 & 27.7 & 22.2 & 43.9 & 22.8 & 33.3 & 0.45 \\
\hline $9 \mathrm{H}-3,134-135$ & 41.9 & 46.6 & 11.5 & 46.5 & 26 & 27.5 & 23.5 & 32.4 & 44.1 & 0.51 \\
\hline $10 \mathrm{H}-2,140-141$ & 40 & 47.4 & 12.6 & 44.9 & 28.2 & 26.9 & 38.9 & 27.8 & 33.3 & 0.49 \\
\hline $12 \mathrm{H}-1,27-28$ & 40.5 & $\begin{array}{l}4,4 \\
47.3\end{array}$ & 12.2 & 44.9 & 23.4 & 31.7 & 39.5 & 32.6 & 27.9 & 0.57 \\
\hline $12 \mathrm{H}-7,22-23$ & 37.4 & 51.6 & 11 & 39.5 & 28.8 & 31.7 & 24.4 & 41.5 & 34.1 & 0.52 \\
\hline $13 \mathrm{H}-5,77-78$ & 44.8 & 35.8 & 19.4 & 54.3 & 23.8 & 21.9 & 20 & 28 & 52 & 0.48 \\
\hline $14 \mathrm{H}-3,67-68$ & 43.3 & 47.3 & 9.4 & 46.3 & 17.4 & 36.3 & 31.4 & 31.4 & 37.1 & 0.68 \\
\hline $15 \mathrm{H}-2,73-74$ & 47.2 & 45.8 & 6.9 & 49.8 & 28.9 & 21.3 & 56 & 20 & 24 & 0.42 \\
\hline $18 \mathrm{H}-2,8-9$ & 36 & $\begin{array}{l}4.0 \\
48.7\end{array}$ & 15.3 & 41.3 & 22.9 & 35.8 & 20.8 & 32.1 & 47.2 & 0.61 \\
\hline $19 \mathrm{H}-1,44-45$ & 39.1 & 45.9 & 15.1 & 43.6 & 19.3 & 37.1 & 37.3 & 17.6 & 45.1 & 0.66 \\
\hline $20 \mathrm{H}-3,14-15$ & 35.4 & 50.4 & 14.2 & 39.5 & 29.8 & 30.8 & 39.2 & 19.6 & 41.2 & 0.51 \\
\hline $2 \mathrm{IH}-2,6-7$ & 39 & 50.9 & 10.2 & 42.1 & 25.5 & 32.5 & 28.6 & 34.3 & 37.1 & 0.56 \\
\hline Average & 41.9 & 44.9 & 13.2 & 47.1 & 24.3 & 28.6 & $\begin{array}{l}20.0 \\
36.3\end{array}$ & 26.0 & 38.1 & 0.53 \\
\hline Standard & 5.8 & 6.2 & 3.3 & 7.0 & 4.2 & 7.4 & 20.5 & 10.0 & 17.4 & 0.09 \\
\hline
\end{tabular}


APPENDIX B (continued)

Beach and Stream Samples from Santa Barbara Region

\begin{tabular}{|c|c|c|c|c|c|c|c|c|c|c|c|c|c|c|c|}
\hline Sample & $\begin{array}{c}\text { Grain } \\
\text { size }\end{array}$ & Qp & Qm & $\mathrm{P}$ & K & Fu & Lvo & Lvv & Lvml & Lvl & Lvf & Lvp & Lmv & Lmm & $\mathrm{Lmt}$ \\
\hline SBB-1 & $\mathrm{m}$ & 7 & 228 & 38 & 54 & 18 & 1 & 1 & 3 & 3 & 4 & 0 & 1 & 0 & 4 \\
\hline SBB-2 & $\mathrm{m}$ & 4 & 113 & 20 & 24 & 31 & 0 & 1 & 3 & 2 & 2 & 0 & 0 & 0 & 6 \\
\hline SBB-3 & $f$ & 11 & 178 & 112 & 36 & 2 & 0 & 1 & 4 & 0 & 13 & 0 & 0 & 2 & 2 \\
\hline SBB-4 & $\mathrm{m}$ & 13 & 105 & 45 & 18 & 7 & 0 & 0 & 0 & 0 & 0 & 0 & 0 & I & 6 \\
\hline SBB-5 & $\mathrm{m}$ & 5 & 243 & 41 & 52 & 8 & 0 & 2 & I & i & 5 & 0 & 0 & i & 1 \\
\hline SBB-6 & m & 10 & 169 & 41 & 37 & 0 & 0 & 4 & 2 & 0 & 4 & 0 & 0 & i & 5 \\
\hline SBB-7 & $\mathrm{m}$ & 14 & 251 & 26 & 40 & 5 & 0 & 3 & 3 & 0 & 9 & 0 & 0 & 0 & 6 \\
\hline SBB-8 & $\mathrm{m}$ & 9 & 244 & 49 & 52 & 0 & 0 & 3 & i & 0 & 7 & 0 & 0 & 0 & 2 \\
\hline SBB-9 & $\mathrm{m}$ & 9 & 198 & 8 & 33 & 5 & 0 & 0 & 1 & 1 & 3 & 1 & 2 & 0 & 11 \\
\hline SBB-10 & $\mathrm{m}$ & 8 & 220 & 48 & 73 & 3 & 0 & 5 & i & 0 & 2 & 2 & 0 & 0 & 3 \\
\hline SBB-1I & $\mathrm{m}$ & 9 & 135 & 40 & 53 & 14 & 0 & 1 & 2 & 0 & 11 & I & 0 & 3 & 10 \\
\hline SBB-12 & $\mathrm{m}$ & 3 & 177 & 47 & 25 & 0 & 0 & $i$ & 3 & 1 & 6 & 0 & 0 & I & 2 \\
\hline SBB-13 & f & 11 & 148 & 73 & 52 & 11 & 0 & 3 & 2 & 0 & 6 & 0 & 0 & 5 & 8 \\
\hline SBB-14 & $\mathrm{m}$ & 4 & 69 & 186 & 0 & $i$ & 0 & 2 & 11 & 14 & 49 & 0 & 0 & 0 & 35 \\
\hline SBB-15 & $\mathrm{m}$ & 3 & 8 & 170 & 2 & 0 & 7 & 17 & 37 & 42 & 27 & 0 & 0 & 0 & 14 \\
\hline SBB-16 & c & 17 & 2 & 23 & 0 & 0 & 0 & 6 & 25 & 12 & 1 & 0 & 0 & 0 & 0 \\
\hline SBB-17 & $\mathrm{m}$ & 7 & 193 & 59 & 84 & 0 & 0 & 5 & 2 & 1 & 7 & 0 & 1 & I & 2 \\
\hline SBB-18 & $\mathrm{c}$ & 5 & 0 & 0 & 0 & 0 & 0 & 0 & 0 & 0 & 0 & 0 & 0 & 0 & 0 \\
\hline
\end{tabular}

\begin{tabular}{|c|c|c|c|c|c|c|c|c|c|c|c|c|c|c|c|}
\hline Sample & $\begin{array}{c}\text { Grain } \\
\text { size }\end{array}$ & Lma & Lsa & Lsc & Lsi & Lsch & Lso & M & Do & Dn & S & $\mathrm{C}$ & Bio & Other & Total \\
\hline SBB-1 & $\mathrm{m}$ & 8 & 4 & 2 & 9 & 2 & 0 & 0 & 1 & 3 & 2 & 1 & 4 & 2 & 400 \\
\hline SBB-2 & $\mathrm{m}$ & 11 & 31 & 5 & 21 & 2 & 8 & 0 & 2 & 0 & 6 & 3 & i & 4 & 300 \\
\hline SBB-3 & f & 6 & 15 & 3 & 4 & 3 & 0 & i & 0 & 1 & 0 & 4 & 2 & 0 & 400 \\
\hline SBB-4 & $m$ & 14 & 48 & 5 & 17 & 8 & 2 & $i$ & 0 & 0 & 0 & 5 & 4 & 1 & 300 \\
\hline SBB-5 & $\mathrm{m}$ & 1 & 14 & 3 & 1 & 7 & 0 & 0 & 4 & 5 & 1 & 1 & 1 & 2 & 400 \\
\hline SBB-6 & $\mathrm{m}$ & 3 & 5 & 1 & 3 & 6 & 0 & 0 & 0 & 2 & 0 & 0 & 3 & 4 & 300 \\
\hline SBB-7 & $\mathrm{m}$ & 5 & 7 & 4 & 3 & 16 & 1 & 0 & 0 & 2 & 0 & 0 & 5 & 0 & 400 \\
\hline SBB-8 & $\mathrm{m}$ & 12 & 9 & 1 & 1 & 7 & 0 & 0 & 0 & 2 & 0 & 1 & 0 & 0 & 400 \\
\hline SBB-9 & $\mathrm{m}$ & 3 & 11 & 3 & i & 6 & 0 & 0 & i & 0 & 0 & i & 2 & 0 & 300 \\
\hline SBB-10 & $m$ & 7 & 10 & 1 & 5 & 6 & 1 & 0 & 0 & 2 & 0 & 0 & 3 & 0 & 400 \\
\hline SBB-11 & $\mathrm{m}$ & 3 & 42 & 3 & 51 & 2 & 4 & 3 & 2 & 5 & 0 & 3 & 3 & 0 & 400 \\
\hline SBB-12 & $\mathrm{m}$ & 7 & 7 & 1 & 6 & $\overline{7}$ & 0 & 0 & i & 3 & 0 & 0 & 2 & 0 & 300 \\
\hline SBB-13 & f & 10 & 31 & 3 & 20 & 1 & 0 & 7 & 4 & 4 & 0 & 0 & 0 & 1 & 400 \\
\hline SBB-14 & $\mathrm{m}$ & 8 & 0 & 0 & 1 & 0 & 0 & 0 & 6 & 12 & 0 & 0 & 2 & 0 & 400 \\
\hline SBB-15 & $m$ & 5 & 4 & 0 & 2 & 0 & 0 & 0 & 15 & 44 & 1 & 0 & 0 & 2 & 400 \\
\hline SBB-16 & $c$ & 0 & 13 & 39 & 2 & 0 & 107 & 1 & 0 & 2 & 0 & 0 & 0 & 0 & 250 \\
\hline SBB-17 & m & 3 & 8 & 1 & 0 & 4 & 7 & 4 & 1 & 0 & 3 & 4 & 2 & 1 & 400 \\
\hline SBB-18 & c & 0 & 0 & 83 & 0 & 10 & 0 & 0 & 0 & 0 & 0 & 1 & 1 & 0 & 100 \\
\hline
\end{tabular}

\begin{tabular}{|c|c|c|c|c|c|c|c|c|c|c|}
\hline Sample & QFL\%Q & QFL\%F & QFL\%L & $\mathrm{QmKP} \% \mathrm{Qm}$ & QmKP\%K & QmKP\%P & LmLvLs\%Lm & LmLvLs\%Lv & LmLvLs\%Ls & $\mathrm{P} / \mathrm{F}$ \\
\hline SBB-1 & 60.7 & 28.4 & 10.9 & 67.5 & 16 & 16.6 & 31 & 28.6 & 40.5 & 0.51 \\
\hline SBB-2 & 41.2 & 26.4 & 32.4 & 60.1 & 12.8 & 27.1 & 18.5 & 8.7 & 72.8 & 0.68 \\
\hline SBB-3 & 48.2 & 38.3 & 13.5 & 54.3 & 11 & 34.8 & 18.9 & 34 & 47.2 & 0.76 \\
\hline SBB-4 & 40.8 & 24.2 & 34.9 & 60 & 10.3 & 29.7 & 20.8 & 0 & 79.2 & 0.74 \\
\hline SBB-5 & 64.2 & 26.2 & 9.6 & 70.6 & 15.1 & 14.2 & 8.1 & 24,3 & 67.6 & 0.49 \\
\hline SBB-6 & 61.5 & 26.8 & 11.7 & 68.4 & 15 & 16.6 & 26.5 & 29.4 & 44.1 & 0.53 \\
\hline SBB-7 & 67.4 & 18.1 & 14.5 & 78 & 12.4 & 9.6 & 19.3 & 26.3 & 54.4 & 0.44 \\
\hline SBB-8 & 63.7 & 25.4 & 10.8 & 70.7 & 15.1 & 14.2 & 32.6 & 25.6 & 41.9 & 0.49 \\
\hline SBB-9 & 69.9 & 15.5 & 14.5 & 81.1 & 13.5 & 5.3 & 37.2 & 14 & 48.8 & 0.28 \\
\hline SBB-10 & 57.7 & 31.4 & 10.9 & 64 & 21.2 & 14.8 & 23.3 & 23.3 & 53.5 & 0.41 \\
\hline SBB-11 & 37.5 & 27.9 & 34.6 & 55.8 & 21.9 & 22.3 & 12 & 11.3 & 76.7 & 0.50 \\
\hline SBB-12 & 61.2 & 24.5 & 14.3 & 71.1 & 10 & 18.9 & 23.8 & 26.2 & 50 & 0.65 \\
\hline SBB-13 & 41.4 & 35.4 & 23.2 & 52.1 & 18.3 & 29.6 & 25.8 & 12.4 & 61.8 & 0.62 \\
\hline SBB-14 & 19.2 & 49.2 & 31.6 & 27 & 0 & 73 & 35.8 & 63.3 & 0.8 & 1 \\
\hline SBB-15 & 3.3 & 50.9 & 45.9 & 4.4 & 1.1 & 94.4 & 12.3 & 83.9 & 3.9 & 0.99 \\
\hline SBB-16 & 7.7 & 9.3 & 83 & 8 & 0 & 92 & 0 & 21.5 & 78.5 & 1 \\
\hline SBB-17 & 51.9 & 37.1 & 10.9 & 57.4 & 25 & 17.6 & 16.7 & 35.7 & 47.6 & 0.41 \\
\hline SBB-18 & 5.1 & 0 & 94.9 & & & & 0 & 0 & 100 & \\
\hline
\end{tabular}

Notes: Grain size: $v f=$ very fine, $f=$ fine, $m=$ medium, and $c=$ coarse; bed size: thin $=<0.2 \mathrm{~m}$ and thick $=>0.2 \mathrm{~m}$. 

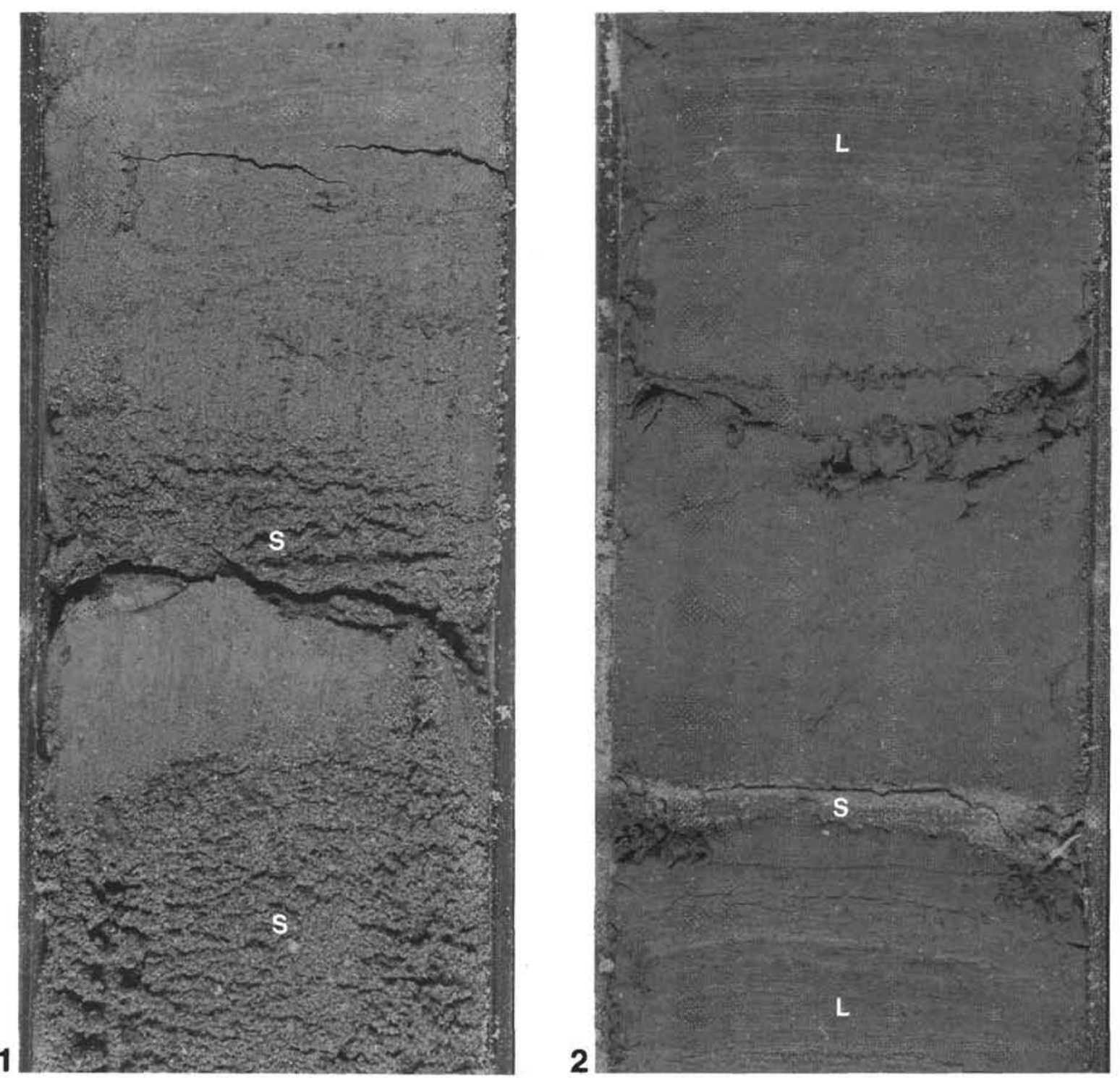

Plate 1. Core photographs of representative sandy intervals. 1. Two sandy layers (S) within Subunit IC (Section 146-893A-8H-2, 38-52 $\mathrm{cm}$ ). Upper sand exhibits an erosional basal contact and a gradational upper contact with diatom silty clay. 2. A thin sandy lamina (S) within massive to laminated (L) or varved silty clay of Subunit IF (Section 146-893A-21H-2, 17-31 cm). 

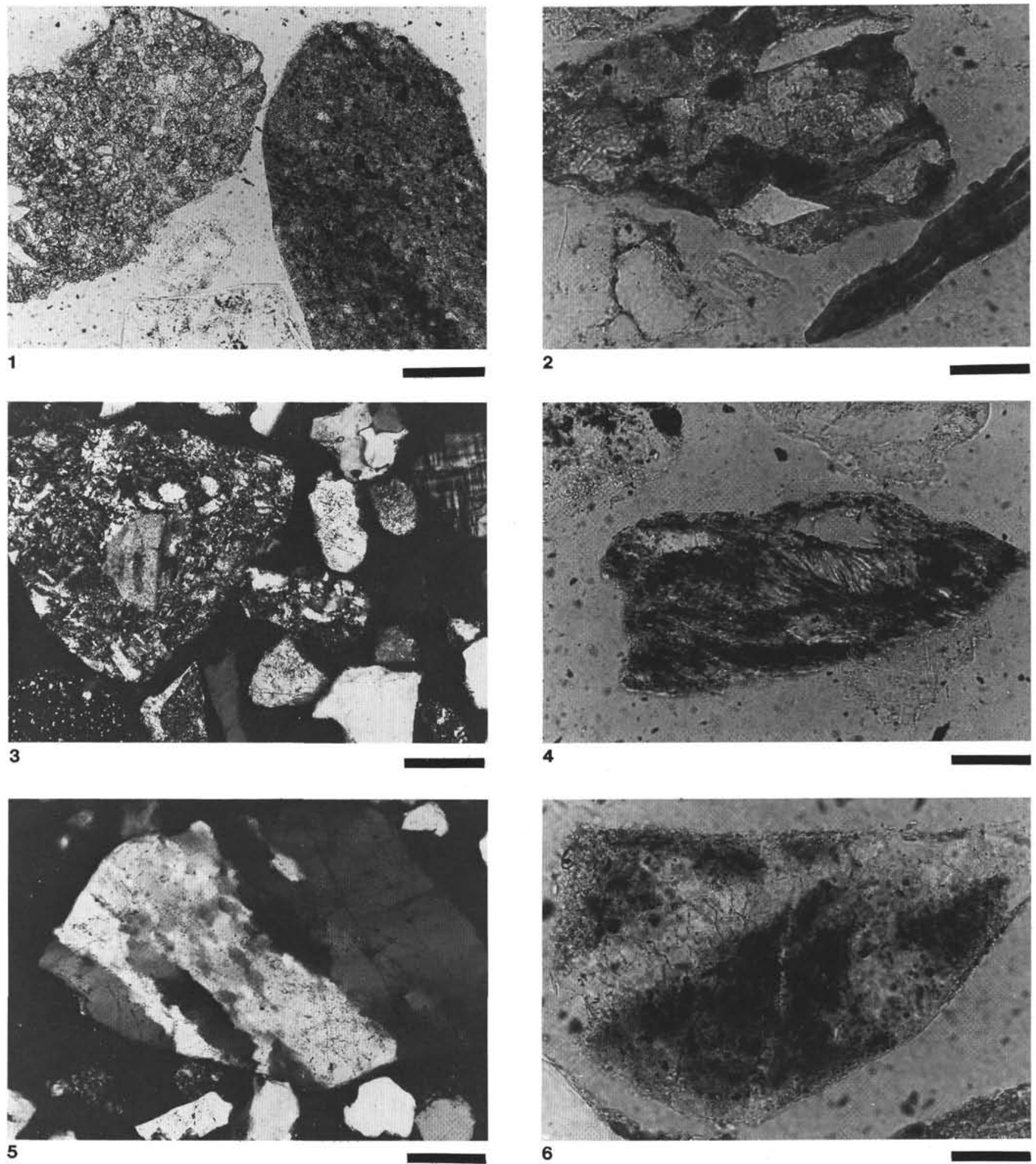

Plate 2. Photomicrographs illustrating various grain types found in Hole 893A sand. 1. Fragment of dirty micrite (marl) on left and silty argillite (mudstone) on right in Sample 146-893A-13H-5, 77-78 cm. Plane-polarized light. Scale bar $=0.1 \mathrm{~mm}$. 2. Fragment of siltstone and biotite grain in Sample 146-893A-13H-5, $77-78 \mathrm{~cm}$. Plane-polarized light. Scale bar $=0.05 \mathrm{~mm}$. 3. Large altered hypabyssal volcanic fragment and smaller grains of feldspar including microcline, quartz, polycrystalline quartz, and sedimentary lithic fragments in Sample 146-893A-13H-3, 77-78 cm. Nicols are crossed, and scale bar $=0.2 \mathrm{~mm} .4$. Lowgrade metasedimentary fragment (quartz-mica tectonite) in Sample 146-893A-13H-5, 77-78 cm. Plane-polarized light. Scale bar $=0.05 \mathrm{~mm} .5$. Metaquartzite fragment in Sample 146-893A-8H-2, 89-90 cm. Nicols are crossed and scale bar $=0.2 \mathrm{~mm}$. 6. Fragment of Fe-oxide-rich, fractured sedimentary chert in Sample I46-893A-6H-4, 94-95 cm. Plane polarized light. Scale bar $=0.05 \mathrm{~mm}$. 